\title{
3. SILICEOUS MICROFOSSILS IN UPPER NEOGENE SEDIMENTS FROM FIVE GUYOTS IN THE WESTERN NORTH PACIFIC, WITH SPECIAL EMPHASIS ON DIATOMS ${ }^{1}$
}

\author{
Juliane Fenner ${ }^{2}$
}

\begin{abstract}
Upper Neogene sediments from six holes (Holes 871A, 872A, 872C, 873B, 878A, and 880A) drilled on five guyots during Leg 144 along a south-north transect were quantitatively analyzed for the abundance of siliceous microfossil groups and diatom species. The occurrence of siliceous microfossils is restricted to the uppermost few meters of the pelagic cap sediments. As a result of dissolution and silica diagenesis, the more dissolution-susceptible diatom valves and silicoflagellate skeletons are absent below 1-2.5 $\mathrm{m}$ core depth in the subtropical sites. In the highly calcareous and highly porous sediments on Limalok, Lo-En, and Wodejebato guyots, siliceous microfossils are now absent from lower Quaternary and upper Neogene sediments. Diatoms of slightly older age (lower Quaternary and Pliocene) are preserved on MIT Guyot. The inverse correlation of the abundance of authigenic zeolites with that of diatoms and other siliceous microfossils indicates that dissolution of biogenic silica provided silica for the formation of the zeolites.

Better preservation of diatoms was found farther north on Takuyo-Daisan Guyot just off Japan. The higher terrigenous component, together with dominant vesicular ash in the Quaternary to upper Pliocene sediments, as well as the higher primary productivity in this region, helped to preserve biogenic silica. Diatom abundance and preservation increased from south to north, which seems to be related to an increase of primary productivity in the west wind-influenced latitudes. Close sample spacing in the upper $70 \mathrm{~cm}$ of Site 880 allows the demonstration of changing eolian input through the last approximately $50,000 \mathrm{yr}$.

The sponge spicule types recovered from the guyots in sediments deposited in water depths between 1200 and $1500 \mathrm{~m}$ are also documented. The paleogeographic distribution of the diatom species occurring in the pelagic sediments are briefly discussed, but preservation was relatively poor.

Diatom biostratigraphy within the upper $7 \mathrm{~m}$ at Site 880 allows identification of the Neodenticula seminae and the Rhizosolenia curvirostris Zones of the North Pacific Diatom Zonation.
\end{abstract}

\section{INTRODUCTION}

During Ocean Drilling Program (ODP) Leg 144, Neogene sediments capping shallow-water limestones and/or volcanic rocks on five guyots in the western North Pacific (Table 1; see site map preceding title page) were cored. These drill holes provide a south-north transect from $5^{\circ} \mathrm{N}$ to $27^{\circ} \mathrm{N}$ and thus offer the chance to study the occurrence and geographic distribution of siliceous microfossils through the upper Neogene section over this latitudinal range.

\section{MATERIAL}

At the three southern sites between $5^{\circ} \mathrm{N}$ and $12^{\circ} \mathrm{N}$, the upper Neogene sediments are yellowish gray to pinkish white, nannofossilrich, foraminifer oozes, containing specks of manganese oxides and hydroxides in some cores. At these three sites, planktonic foraminifers are highly conspicuous components of the sediment, giving it its sandy texture. This, together with the high water content $(80 \%-$ $150 \%$ ) of the sediments (Premoli Silva, Haggerty, Rack, et al., 1993) resulted in the liquefaction of the pelagic cap sediments from Holes $871 \mathrm{~A}$ and $872 \mathrm{~A}$ during handling of the cores on deck. The sedimentfilled plastic liners were not completely filled, and parts of the sediment flowed back and forth within the liners. Thus, these cores cannot be used for detailed micropaleontological studies. When the cores for Holes $872 \mathrm{C}$ and $873 \mathrm{~B}$ reached the deck, they were left in an upright position for several hours. In addition, a perforated lid (a "piglet") was placed on the sediment surface. Before the cores were split lengthwise, the water that had collected at the top was drained. This procedure hindered sediment mixing within the core liner and helped

\footnotetext{
${ }^{1}$ Haggerty, J.A., Premoli Silva, I., Rack, F., and McNutt, M.K. (Eds.), 1995. Proc $O D P$, Sci. Results, 144: College Station, TX (Ocean Drilling Program).

2 Bundesanstalt für Geowissenschaften und Rohstoffe, Stilleweg 2, D-30655 Hannover, Federal Republic of Germany.
}

to hold the sediment in place. These cores can be used for detailed micropaleontological analysis.

Farther north, at Site 878, pelagic sediments are rich in manganese micronodules and are yellowish brown in color. The water content of these sediments was only $50 \%-80 \%$, much less than at the southern sites. At Site 880 , the northernmost site drilled, the sediments were grayish brown to olive gray and contained a high percentage of terrigenous matter and volcaniclastic material. The sediments also had a much firmer consistency, having a water content between $46 \%$ and $70 \%$ (Premoli Silva, Haggerty, Rack, et al., 1993), so the use of the piglet was unnecessary.

\section{METHODS}

Between 10 and $25 \mathrm{~g}$ of sediment sample was necessary to obtain a sufficient number of siliceous microfossils of the Neogene foraminifer sands from Holes 871A, 872A, 872C, and 873B. Only 3-10 $\mathrm{g}$ was necessary at Site 878 , and about $0.5 \mathrm{~g}$ was sufficient at Site 880 . The sediment samples were prepared quantitatively so that the number of diatom valves per gram sediment could be determined. In addition, the weight of the total $\mathrm{CH}_{3} \mathrm{COOH}$-insoluble residue $>2 \mu \mathrm{m}$ was determined.

The weighed, dry samples were treated only with $10 \%$ $\mathrm{CH}_{3} \mathrm{COOH}$. Slides were prepared from the insoluble residue with a known aliquot of the sample and a statistically random distribution following the method of Battarbee (1973).

Hyrax was used as the embedding resin (refractive index $n=1.71$; solvent: toluene). The slides were scanned at a $1000 \times$ magnification under a Zeiss Axioplan microscope using a 100 $\times$ Plan-APOCHROMAT oil immersion objective with a numerical aperture of 1.40 . If possible, a minimum of 300 siliceous microfossils, or 100 diatoms in Hole $880 \mathrm{~A}$, was counted per sample. The counts are related to the dry weight of the sediment and corrected for the salt content from the evaporated pore water. 
Table 1. Geographic location of Leg 144 holes studied and thickness of Neogene pelagic sediment column recovered.

\begin{tabular}{|c|c|c|c|c|c|}
\hline Hole & Guyot & $\begin{array}{l}\text { Latitude } \\
\text { (N) }\end{array}$ & $\begin{array}{l}\text { Longitude } \\
\text { (E) }\end{array}$ & $\begin{array}{c}\text { Water } \\
\text { depth } \\
\text { (m) }\end{array}$ & $\begin{array}{l}\text { Recovered } \\
\text { Neogene } \\
\text { section } \\
\text { (m) }\end{array}$ \\
\hline $871 \mathrm{~A}$ & Limalok (Harrie) & $05^{\circ} 33.432^{\prime}$ & $172^{\circ} 20.658^{\prime}$ & 1254.6 & 133.7 \\
\hline $872 \mathrm{~A}$ & Lo-En & $10^{\circ} 05.850^{\prime}$ & $162^{\circ} 51.960^{\prime}$ & 1083.6 & 120.0 \\
\hline $872 \mathrm{C}$ & Lo-En & $10^{\circ} 05.620^{\prime}$ & $162^{\circ} 52.002^{\prime}$ & 1082.1 & 126.0 \\
\hline $873 B$ & Wodejebato & $11^{\circ} 53.838^{\prime}$ & $164^{\circ} 55.230^{\prime}$ & 1334.0 & 53.0 \\
\hline $878 \mathrm{~A}$ & MIT & $27^{\circ} 19.143^{\prime}$ & $151^{\circ} 53.028^{\prime}$ & 1323.2 & 3.2 \\
\hline $880 \mathrm{~A}$ & Takuyo-Daisan (Seiko) & $34^{\circ} 12.053^{\prime}$ & $144^{\circ} 18.074^{\prime}$ & 1524.8 & 18.4 \\
\hline
\end{tabular}

The microscopic identification of zeolites was checked in selected samples using X-ray diffraction analysis (H. Rösch, BGR, Hannover). The surface sediment sample from Hole 872A did not contain actual surface sediment. It consisted of older material that must have been washed out during handling of the core on deck and then settled on top. The results from this sample are included in the tables but were omitted from the figures.

\section{RESULTS AND DISCUSSION}

\section{Siliceous Microfossil Groups}

The main marine siliceous microfossil groups (diatoms, radiolarians, sponge spicules, and archaeomonadaceae) are present in the surface sediments at all sites. The most dissolution-susceptible silicoflagellates occur only sporadically. Pollen (tricolpate and bisaccate types) and dinoflagellates occasionally occur in the $\mathrm{CH}_{3} \mathrm{COOH}$ insoluble residue also (Pl. 2, Figs. 12-14).

Because the occurrence of siliceous microfossils is restricted to the surface near part of the pelagic cap sequence, only the upper few meters of each hole were analyzed for this study. The only exception to this is the northernmost site (Site 880).

At the sites in the tropical-subtropical belt (Figs. 1-3; Tables $2-5,7-10$ ), the abundance of all siliceous microfossils decreases significantly within the upper $1-3 \mathrm{~m}$ of the sediment column. Further downcore, the $\mathrm{CH}_{3} \mathrm{COOH}$-insoluble residue of the pelagic cap sediments is dominated by authigenic silicates. As in the sediments mentioned previously, quartz grains, volcanic ash, phosphatic remains, and $\mathrm{Fe}$ and $\mathrm{Mn}$ oxides and hydroxides also occur. The main zeolites are clinoptilolite and phillipsite. In these sediments, which are practically barren of siliceous microfossils, only sporadic archaeomonadaceae (the most dissolution-resistant siliceous microfossil group) and very rare single fragments of radiolarians or diatoms occur.

Overall, the abundance of the siliceous microfossil groups in the highly calcareous sediments at the three southern sites (Sites 871, 872 , and $873=93 \%-98 \% \mathrm{CaCO}_{3}$ ) is very low. Even the highest abundance of diatom valves is only on the order of $10^{3}$ per gram of sediment. That of the silicoflagellates is 1 order of magnitude lower still. The abundance of diatoms at these sites drops below the recognizable limit (below $10^{1.5}$ valves per gram of sediment) within the uppermost 1.5-2 m of cored sediment. The more dissolution-resistant siliceous microfossil groups of radiolarians, sponge spicules, and Archaeomonadaceae can reach higher abundances (up to $10^{4}$ specimens per gram sediment) and can also be traced farther downcore.

Further evidence that the abundance of siliceous microfossils at these sites is controlled by dissolution is the downcore increase in fragmentation, etching, and partial recrystallization of these microfossils. The inverse correlation of the abundance of the siliceous microfossils and zeolites suggests that these authigenic silicates have drawn silica for their formation from the dissolution of biogenic opal.

At the three southern sites, the $\mathrm{CH}_{3} \mathrm{COOH}$-insoluble residue $>2$ $\mu \mathrm{m}$, which is composed of wind-transported material (mainly volcanic ash) as well as biosiliceous particles, zeolites, and Fe and Mn oxides and hydroxides, is $<1 \%$ of the bulk sediment. Further north at Site 878, the $\mathrm{CH}_{3} \mathrm{COOH}$-insoluble residue $>2 \mu \mathrm{m}$ is $>10 \%$ (Table 10;
Fig. 4). According to the age determined for the pelagic cap sediments at this site by Erba (Premoli Silva, Haggerty, Rack, et al., 1993), Holocene and upper Pleistocene sediments are missing and lower Pleistocene and older sediments were recovered in Core 144-878AIR. Volcanic ash particles are the dominant component (vesicular ash is rare) in the $\mathrm{CH}_{3} \mathrm{COOH}$-insoluble residue together with $\mathrm{Fe}$ and $\mathrm{Mn}$ oxides and hydroxides. The abundance of siliceous microfossils is still relatively low (on the order of $10^{3}$ ), and they persist into much older sediments than at the sites farther south.

At the northernmost site (Site $\mathbf{8 8 0}$ off Japan, on Takuyo Daisan Guyot), the situation is completely different. Here, the $\mathrm{CH}_{3} \mathrm{COOH}$ insoluble residue $>2 \mu \mathrm{m}$ makes up between $40 \%$ and $90 \%$ of the bulk sediment. Most of this residue is silt- to sand-sized vesicular ash, giving the sediment its gray color and causing the dark specks. Only two cores were recovered at this site. Siliceous microfossils are present here in much higher abundance than they are at the sites studied farther south (e.g., silicoflagellates reach abundances of $10^{5}$ skeletons per gram sediment). They occur down to the base of the cored interval (Fig. 5). This, combined with the absence of zeolites, indicates that silica diagenesis was much slower than at the more southern sites. Nevertheless, a distinct stepwise decrease in the preservation of biosiliceous remains is also recognizable at this site. Adecrease in diatom abundance (from an average of $10^{5}$ to $<10^{4}$ valves/g sediment) occurs at $7 \mathrm{mbsf}$ in the core within the Pseudoemiliania lacunosa Zone (Erba, this volume). Also, the abundance of silicoflagellates and radiolarians decreases at this core depth (Fig. 5). The occurrence of Spermatogonia sp. and Actiniscus sp. (dinoflagellates with internal siliceous spicules) is restricted to these upper $7 \mathrm{~m}$ of the sediment column. Here, diatom abundance fluctuates strongly between $10^{3}$ and $10^{6}$ valves per gram sediment. Below $7 \mathrm{~m}$ core depth, only the most dissolution-resistant diatom valves or fragments and the more robust radiolarian species are left. Variations in diatom abundance are comparatively small (between $10^{3}$ and $10^{4}$ valves/g sediment). A second step in the decrease of preservation is reflected at $15 \mathrm{~m}$ core depth by the relative increase of the more dissolution-resistant radiolarians and freshwater diatoms as compared with the less dissolution-resistant marine diatoms (Fig. 6).

The overall much better preservation of siliceous microfossils at Site 880 may result in part from a higher productivity in these waters just off Japan. On the other hand, dissolved silica from the abundant vesicular ash in these sediments may help preserve the biogenic silica. Unfortunately, no analyses of dissolved silica in the pore waters of Hole $880 \mathrm{~A}$ are available. For the sandy foraminifer oozes on Limalok, Lo-En, and Wodejebato guyots, pore-water analyses yielded characteristic seawater values and no downcore gradients. This indicates that pore-water flow, and possibly flushing of the sediment column during core recovery, controlled the concentration of ions in dissolution (Opdyke, this volume), but diffusion did not.

A close sample spacing was obtained of one sample every $2-3 \mathrm{~cm}$ for the upper $66 \mathrm{~cm}$ of core, allowing for checking of climate-related changes in the abundance and preservation of siliceous microfossils.

A special characteristic of Site 880 is the relatively high and frequent occurrence of phytoliths and freshwater diatoms (Fig. 5; Table 6; Pl. 2, Figs. 15-25), including members of the Aulacoseira granulata group, Stephanodiscus sp., and a single specimen each of Navicula sp., Fragilaria sp., Cocconeis placentula, Cymbella sp., Cyclotella sp., Eunotia sp., Epithemia sp., and Achnanthes sp. Pollen grains were also frequently found in samples from this site (Table 6). These three component groups suggest a definite input of windblown material by west winds. The upper $70 \mathrm{~cm}$ of this hole belongs to the Emiliania huxleyi Acme Zone (Erba, this volume); thus, this segment is younger than 70,000 yr. The abundance changes of vesicular ash and the different siliceous microfossil groups (except for freshwater diatoms) all show a similar trend (Figs. 5, 7). Their abundances drop slightly and gradually upsection, reaching minimum values at a core depth of 20 to $5 \mathrm{~cm}$. In the upper $5 \mathrm{~cm}$, the abundances of all these components strongly increase, in most cases by more than 1 order of magnitude. 


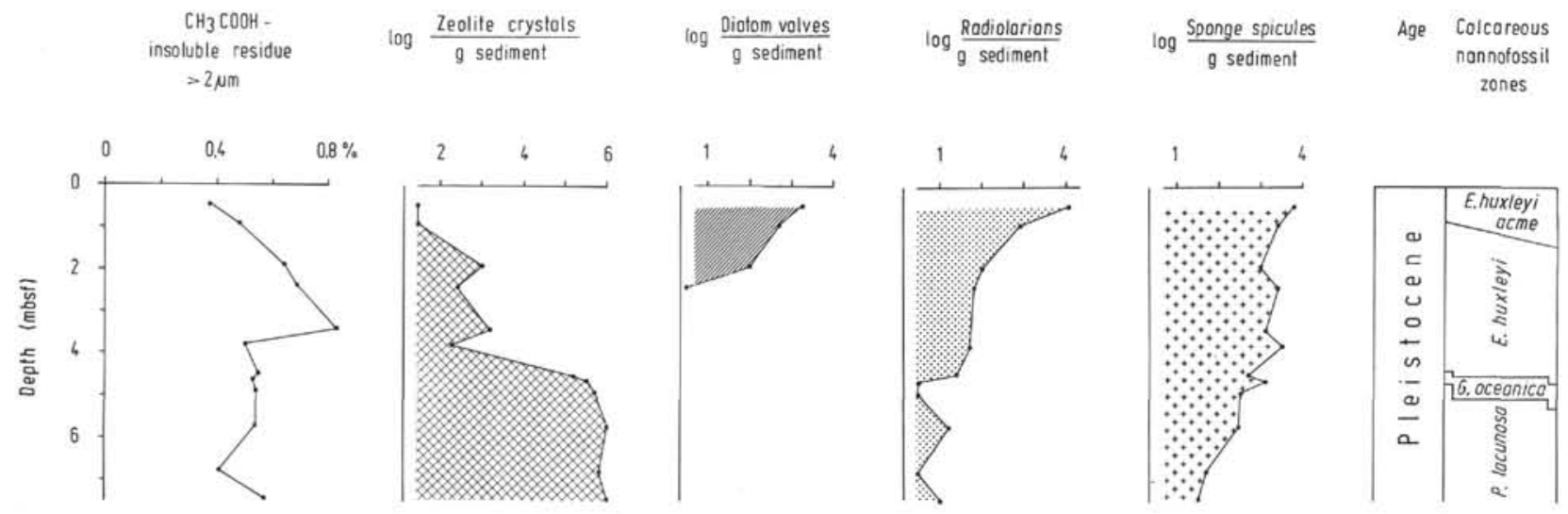

Figure 1. Abundance of the $\mathrm{CH}_{3} \mathrm{COOH}$-insoluble residue $>2 \mu \mathrm{m}$, zeolites, and major siliceous microfossil groups in upper Quaternary sediments from Hole $871 \mathrm{~A}$. Calcareous nannofossil zones after Premoli Silva, Haggerty, Rack, et al. (1993).

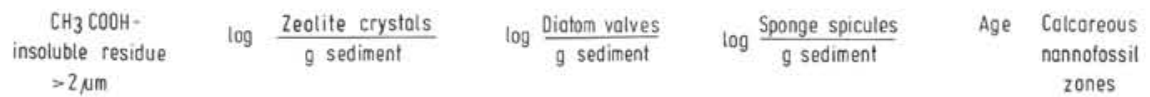
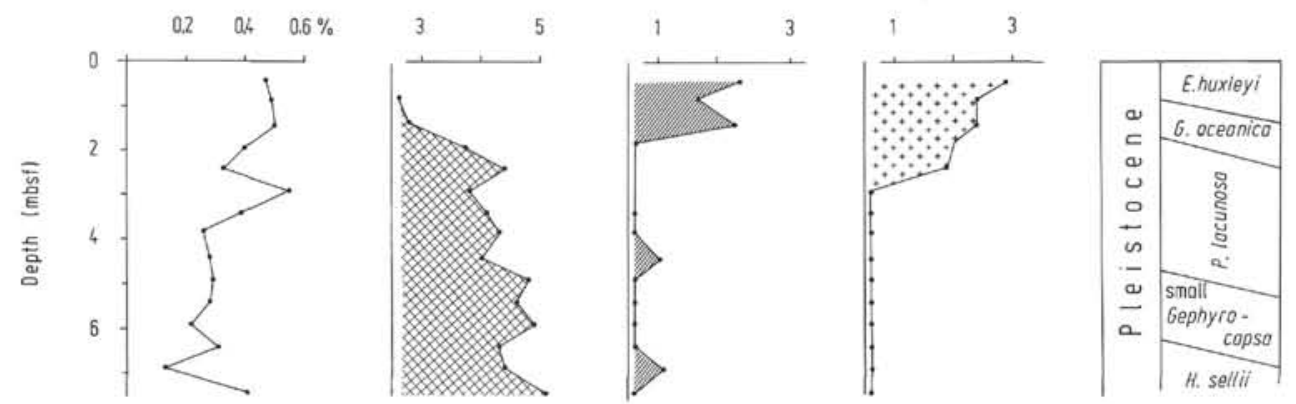

Figure 2. Abundance of the $\mathrm{CH}_{3} \mathrm{COOH}$-insoluble residue $>2 \mu \mathrm{m}$, zeolites, and major siliceous microfossil groups in Quaternary sediments from Hole $872 \mathrm{~A}$. Calcareous nannofossil zones after Premoli Silva, Haggerty, Rack, et al. (1993).

Table 2. Occurrence of diatom species in samples from the upper Quaternary pelagic sediments, Hole 871A.

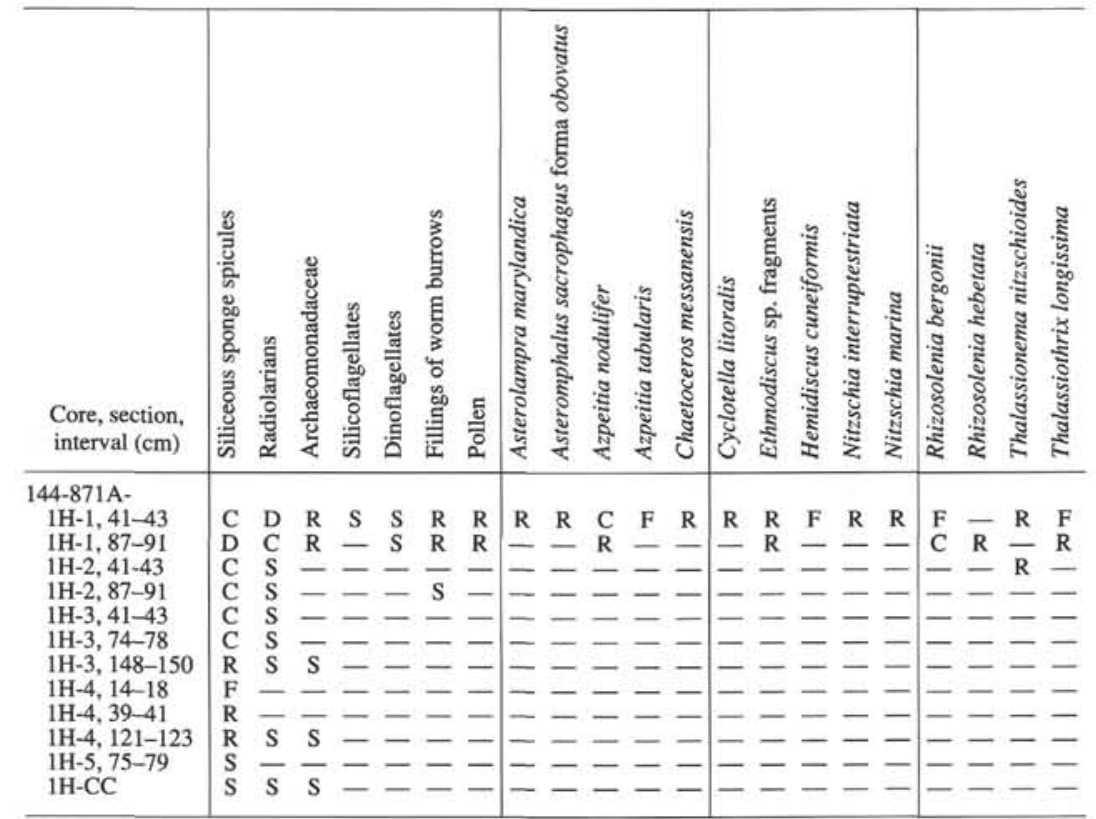

Notes: The abundance of each species and of the microfossil groups is given as follows: $\mathrm{S}($ scarce $)=<1 \%, \mathrm{R}(\mathrm{rare})=1 \%-3 \%, \mathrm{~F}(\mathrm{few})=3 \%-10 \%, \mathrm{C}$ (common) $=10 \%-30 \%$, and D $($ dominant $)=>30 \%$. 




Figure 3. Abundance of the $\mathrm{CH}_{3} \mathrm{COOH}$-insoluble residue $>2 \mu \mathrm{m}$, zeolites, and major siliceous microfossil groups in Quaternary sediments from Hole $873 \mathrm{~B}$. Calcareous nannofossil zones after Premoli Silva, Haggerty, Rack, et al. (1993).



$$
\begin{aligned}
& >2 \mu \mathrm{m}
\end{aligned}
$$
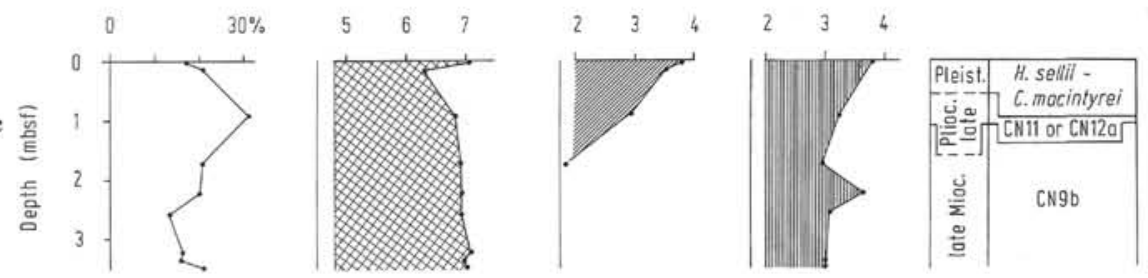

Table 3. Occurrence of diatom species in samples from the Quaternary pelagic sediments, Holes 872A and 872C.

\begin{tabular}{|c|c|c|c|c|c|c|c|c|c|c|c|c|c|c|c|c|c|c|c|}
\hline $\begin{array}{l}\text { Core, section, } \\
\text { interval }(\mathrm{cm})\end{array}$ & 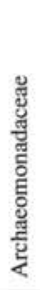 & 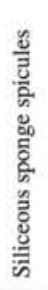 & 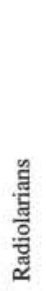 &  &  & $\frac{5}{\overline{0}}$ & 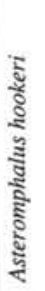 & 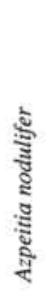 & 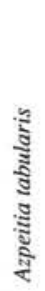 & 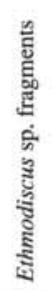 & 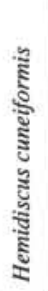 & 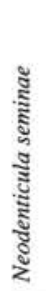 & 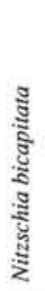 & 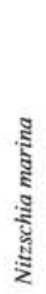 & 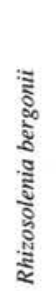 & 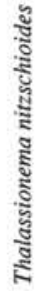 & 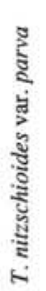 &  & 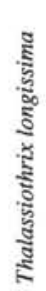 \\
\hline 144 & & & & & & & & & & & & & & & & & & & \\
\hline $1 \mathrm{H}-1,39$ & $\underset{\mathrm{F}}{\mathrm{S}}$ & $\begin{array}{l}\mathrm{S} \\
\mathrm{C}\end{array}$ & $\begin{array}{l}\mathrm{R} \\
\mathrm{C}\end{array}$ & $\bar{z}$ & $\underline{\mathrm{R}}$ & $=$ & E & $\bar{R}$ & 二 & $\bar{z}$ & $\bar{z}$ & Z & $\overline{\mathrm{s}}$ & $\bar{F}$ & $\overline{\mathrm{R}}$ & $\bar{R}$ & $\bar{z}$ & $\bar{z}$ & 二 \\
\hline & F & $\mathrm{F}$ & $\mathrm{F}$ & - & s & - & & - & $\overline{-}$ & 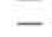 & $=$ & & - & 0 & $\mathrm{~K}$ & - & - & - & \\
\hline $1 \mathrm{H}-$ & $\mathbf{R}$ & $\mathrm{F}$ & $\mathrm{R}$ & - & - & - & 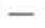 & $\mathrm{R}$ & - & - & - & $\mathrm{R}$ & - & R & - & - & $\mathrm{R}$ & - & $\mathbf{R}$ \\
\hline 1H & R & $\mathrm{R}$ & $F$ & - & - & - & & - & - & - & - &  & - & - & - & - & - & - & - \\
\hline $1 \mathrm{H}$ & R & $\mathrm{R}$ & - & - & - & - & - & - & - & - & - & - & - & - & - & - & - & - & - \\
\hline & &  & S & - & - & - & &  & - & & & & - & & & 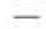 & & & - \\
\hline & $\mathbf{R}$ & - & - & - & - &  & & - & - & - & - & - & - & - & - & - & & - & - \\
\hline $1 \mathrm{H}-$ & R & - & - & - & - & - & & - & - & - & - & $\bar{c}$ & - & - & - & - & 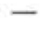 & - & - \\
\hline-144 & - & - & - & - & - & - & & - & - & - & - & S & - & - & - & - & - & - & - \\
\hline $1 \mathrm{H}-$ & $R$ & - & - & - & $S$ & - & & - & - & - & - & & - &  & - & - & 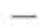 & - & - \\
\hline & & & - & - & & - & & & & & & & & & & & & & - \\
\hline 144 & $\mathrm{R}$ & - & - & - & $\mathrm{R}$ & S & & - & - & & 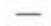 & & - & & & - & & - & - \\
\hline $1 \mathrm{H}$ & R & - & - & - & $\mathrm{F}$ & $\mathrm{R}$ & & - & - & - & - & - & - & - & 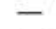 & - & & - & - \\
\hline & $\mathrm{R}$ & - & - & - & R & - & & 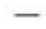 & - & - & - & $S$ & - & - & - & - & - & - & - \\
\hline $1 \mathrm{H}-\mathrm{C}$ & C & $\mathrm{F}$ & C & - & R & S & - & - & - & - & - & - & - & - & - & - & - & - & - \\
\hline $144-8$ & & & & & & & & & & & & & & & & & & & \\
\hline & $F$ & C & C & - & - & - & - & $\mathrm{S}$ & - & - & - & - & - & - & - & - & - & $S$ & $\mathrm{~S}$ \\
\hline & & 0 & S & & & - & & & & & $\mathrm{S}$ & & & & & S & & - & S \\
\hline & C & $\mathrm{F}$ & C & - & - & S & & S & $S$ & $S$ & 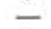 & & & S & - & - & & - & - \\
\hline & $\mathrm{F}$ & $\mathrm{F}$ & C & - & - & 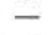 & & 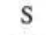 & 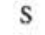 &  & n & & & S & & $\bar{c}$ & & & \\
\hline & $\mathrm{E}$ & $\mathrm{F}$ & $\mathrm{F}$ & - & - & - & $\mathrm{S}$ & - & - & - & S & & - & & - & $\mathrm{S}$ & & - & \\
\hline $1 \mathrm{H}-1,90-94$ & C & $\mathrm{F}$ & $\mathrm{R}$ & - & - & - & - & - & - & - & - & - & - & S & - & - & - & - & - \\
\hline
\end{tabular}

Note: See Table 2 for explanation of abbreviations. 
Table 4. Occurrence of diatom species in samples from the Quaternary pelagic sediments, Hole 873B.

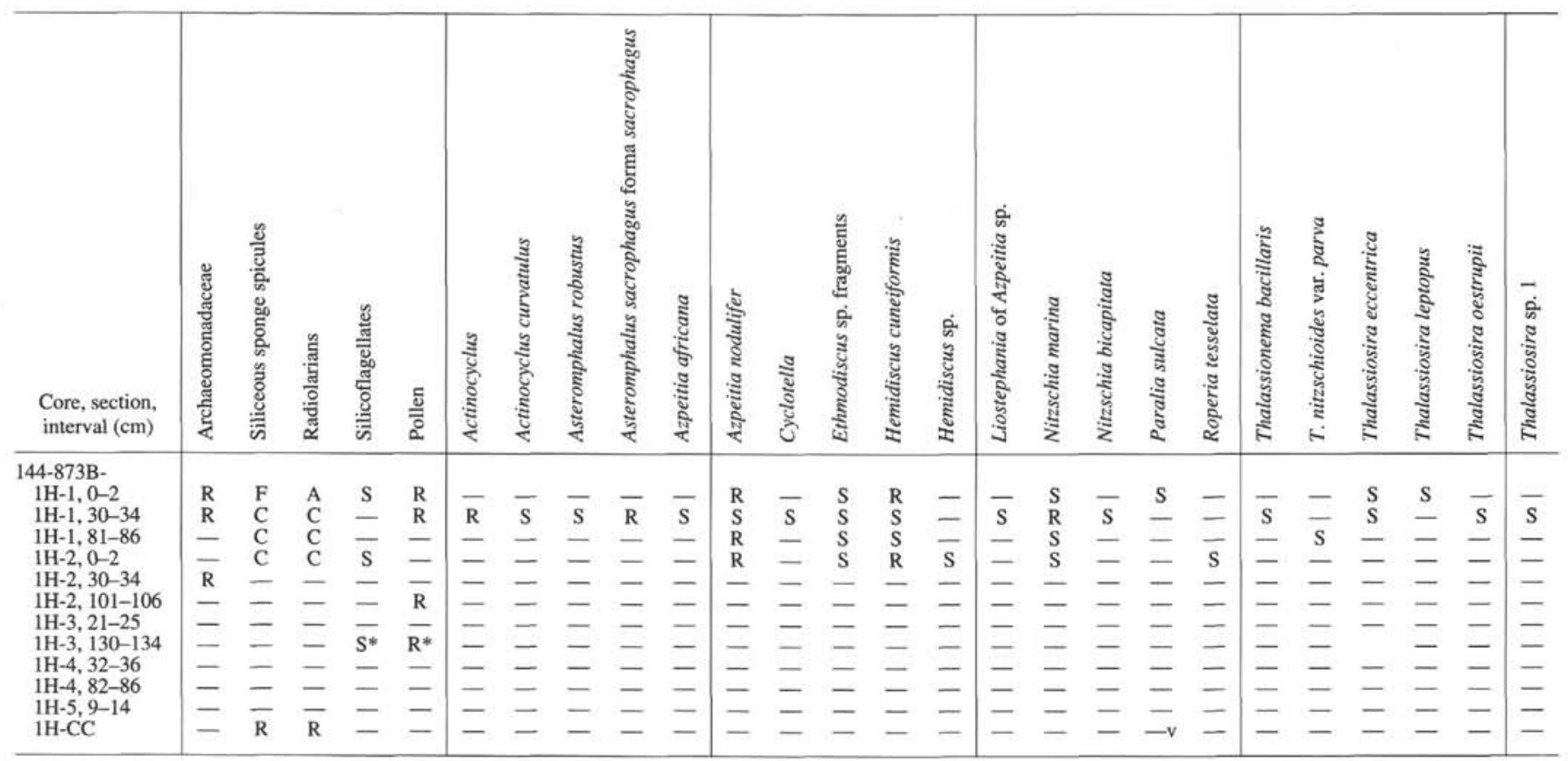

Notes: See Table 2 for explanation of abbreviations. Single asterisk $(*)=$ only Mn-hydroxide crusts from former microfossils are left.

Table 5. Occurrence of diatom species in samples from the Neogene pelagic sediments, Hole 878A.

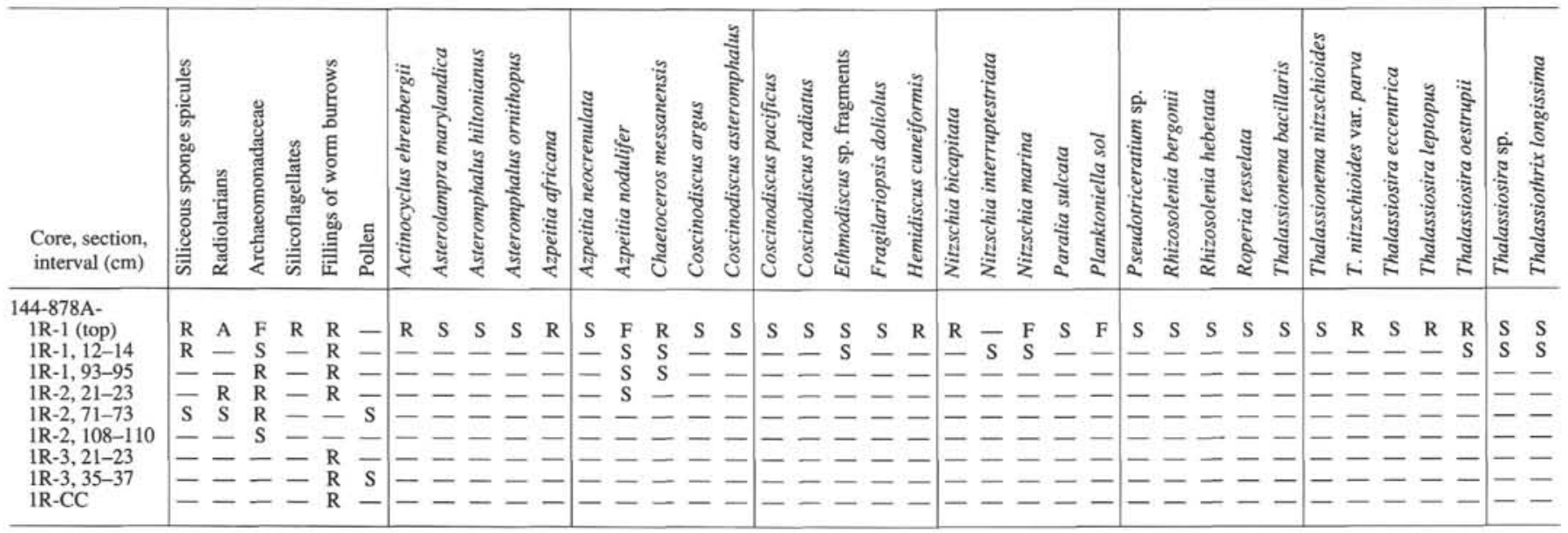

Note: See Table 2 for explanation of abbreviations.

Because of the covariance of components from different sources (e.g., marine planktonic diatoms and vesicular ash), the abundance changes of the siliceous microfossil groups are not controlled by dilution with volcanic ash (Figs. 5, 6). Rather, the more ash present, the greater the number of siliceous microfossils, the higher their diversity, and the better their preservation. The abundance changes may result from two factors: (1) the abundant presence of vesicular ash in the sediments helps preserve siliceous microfossils and (2) the abundance fluctuations of volcanic ash and biosiliceous particles may be controlled by the same cause. This cause could be climate-related changes in the west wind intensity or in aridity and, consequently, in dilution by windblown detritus. However, it could also be dilution by $\mathrm{CaCO}_{3}$, thus changing the productivity of biogenic carbonate producers. Unfortunately, no detailed $\mathrm{CaCO}_{3}$ determinations yet exist for this hole. The ratio of freshwater to marine diatoms (Fig. 7) indicates that windblown detritus originating from west of the site has increased during the time interval represented in the core between 20 and $5 \mathrm{~cm}$ depth bsf.

Isotopic studies would have been helpful for the interpretation. In their absence, this interval is interpreted to represent the last glacial maximum and Isotopic Stage 2. The rise in abundance in the upper 5 $\mathrm{cm}$ is interpreted to represent Termination I, and most of Isotopic Stage 1 would be missing. If this interpretation is correct, the time interval of the last glacial maximum was a period of increased wind intensity and of increased aridity in the coastal mainland west of the site, thus forming a source area for the windblown dust deposited offshore.

Below $66 \mathrm{~cm}$, the spacing of the samples is too far apart to allow such study. Here, a clear cyclicity in abundances of eolian components that would indicate changes between more arid and more humid conditions in the hinterland cannot be recognized. Abundance of 


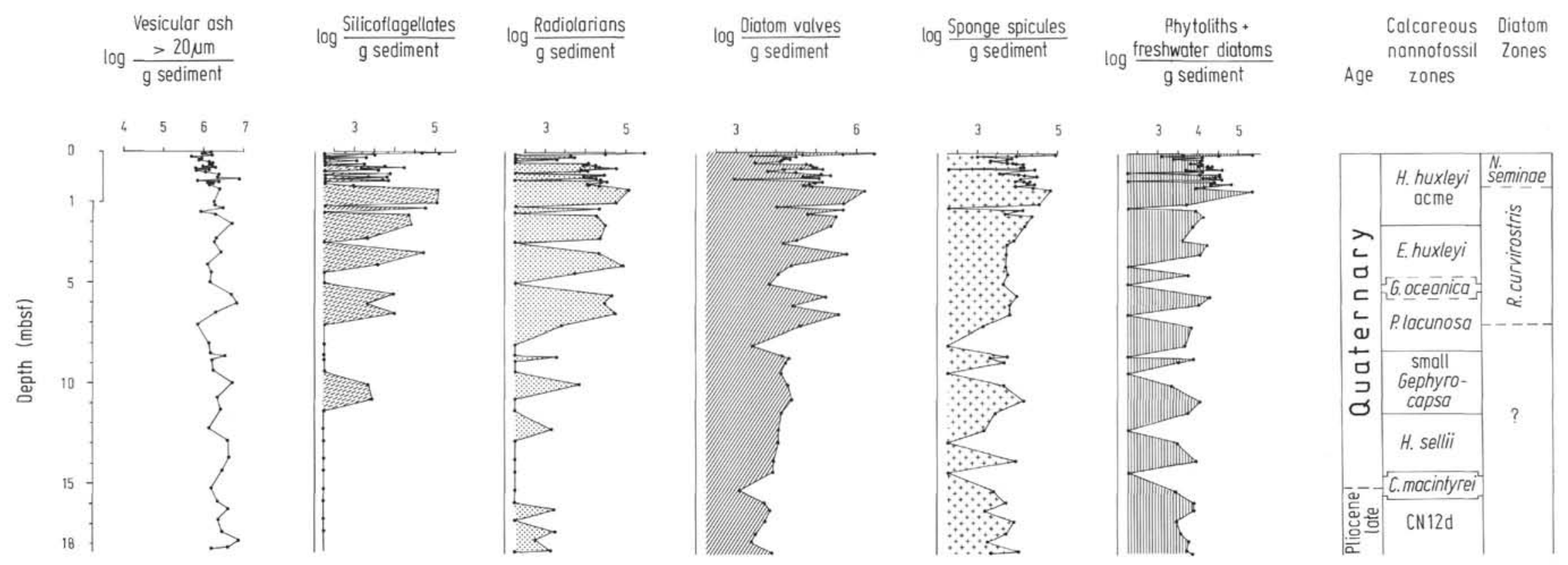

Figure 5. Abundance of vesicular ash $>20 \mu \mathrm{m}$ and the major siliceous microfossil groups in upper Pliocene to Quaternary sediments from Hole $880 \mathrm{~A}$ plotted on a logarithmic scale. Note the different scale for the uppermost meter of the core depth. Calcareous nannofossil zones after Premoli Silva, Haggerty, Rack, et al. (1993). 


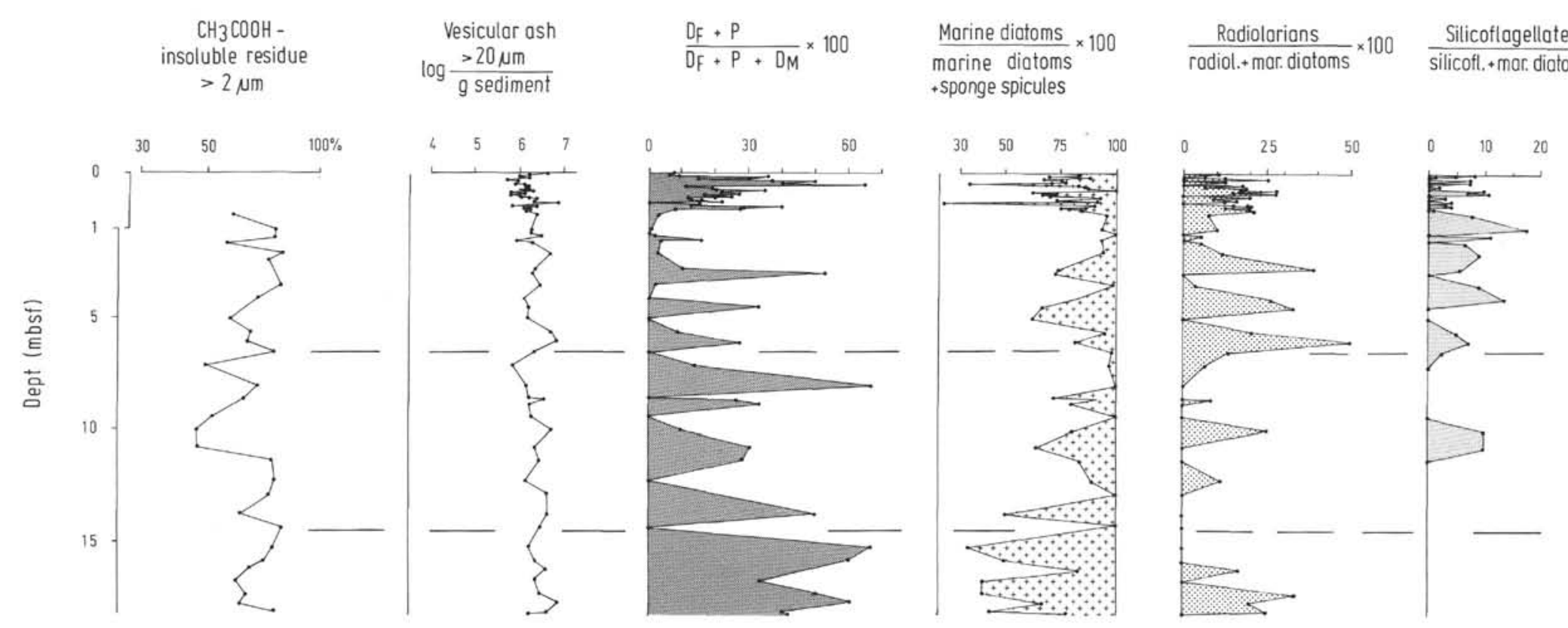

Figure 6. Abundance of vesicular ash $>20 \mu \mathrm{m}, \mathrm{CH}_{3} \mathrm{COOH}$-insoluble residue $>2 \mu \mathrm{m}$, and siliceous microfossil groups of different dissolution-susceptibility and of nonmarine vs. marine diatoms ( $\mathrm{D}$ $=$ marine diatoms, $D_{F}=$ freshwater diatoms, $\mathrm{P}=$ phytoliths) in Hole 880A. Note the different scale for the core depth in the uppermost meter. The dashed lines mark steps of decreasing preservation of biogenic silica. 


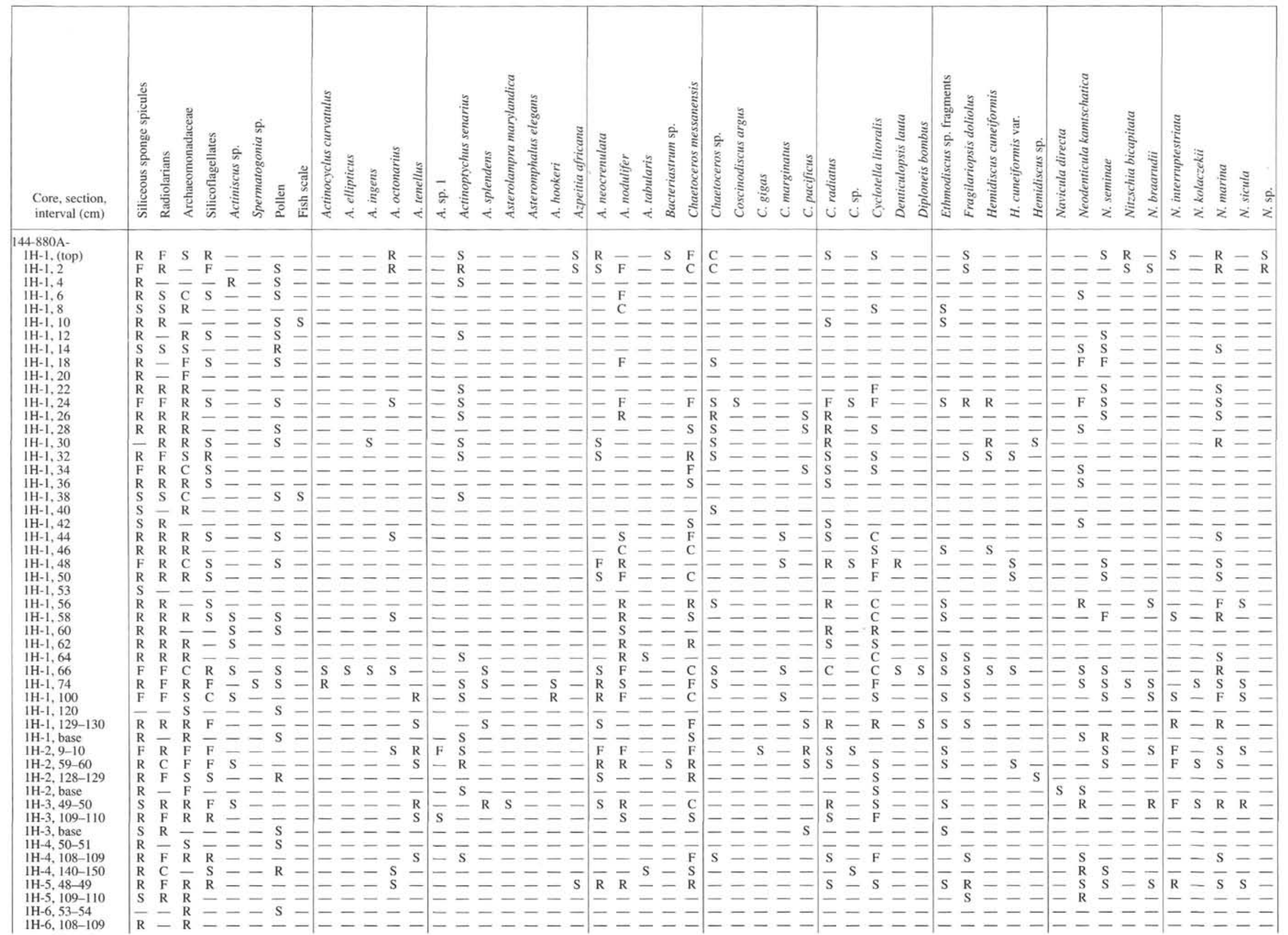


Table 6 (continued).

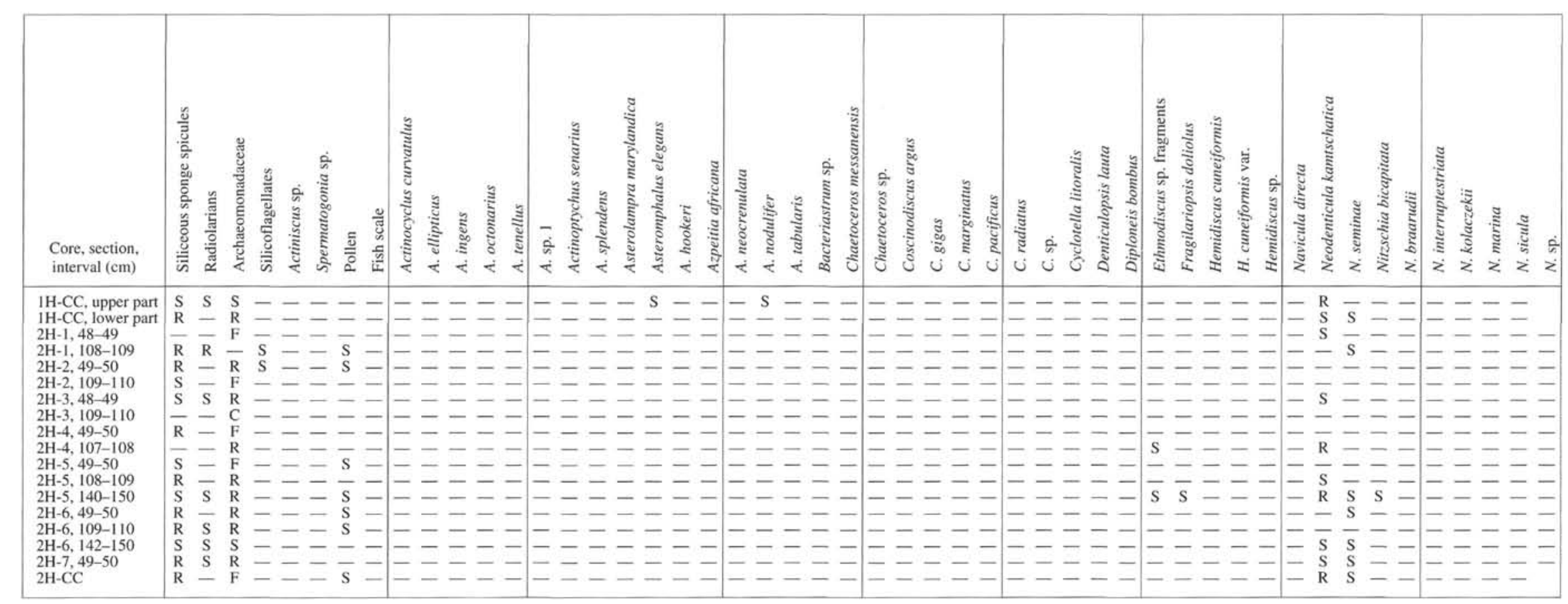


Table 6 (continued).

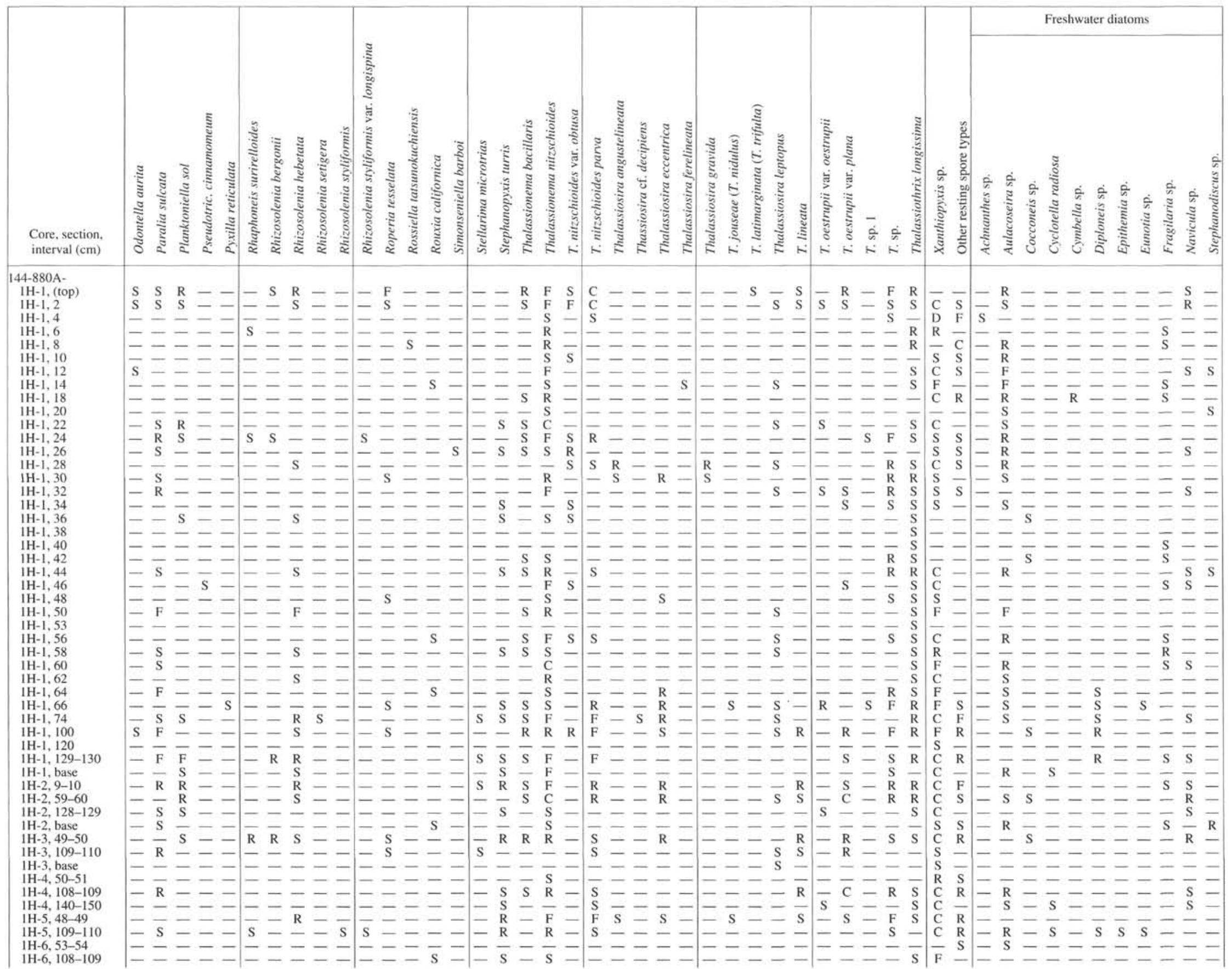


Table 6 (continued).

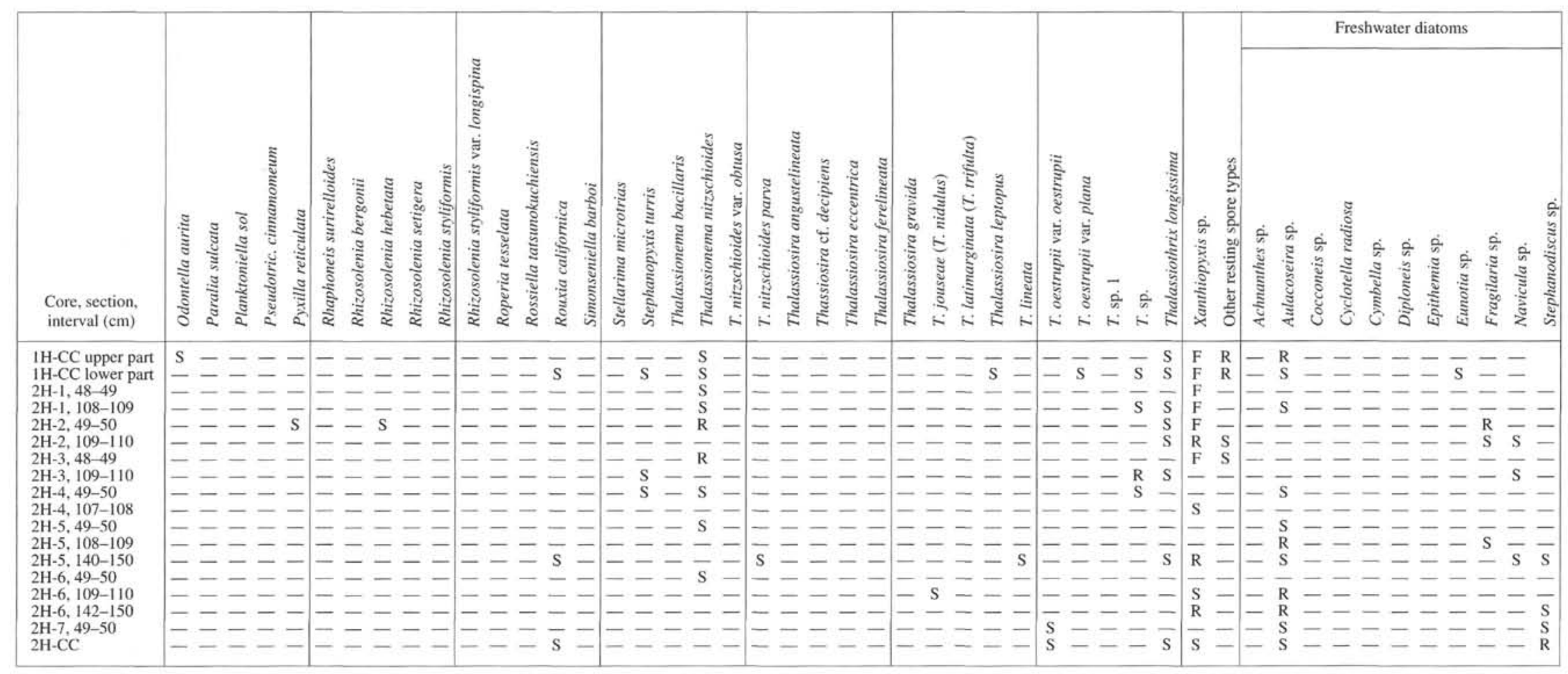



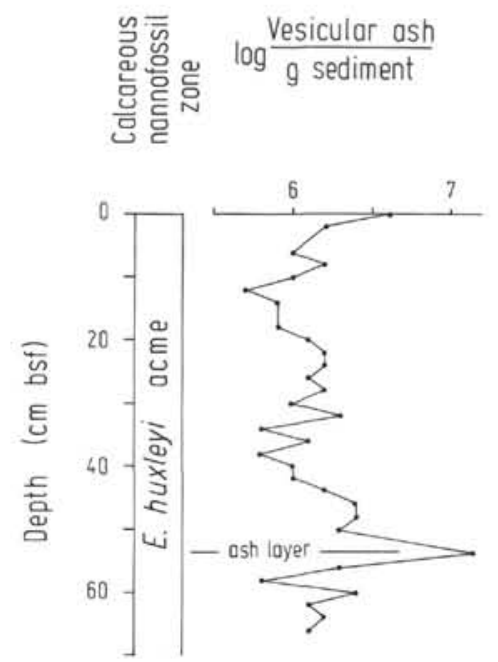

$\log \frac{\text { Marine diatoms }}{g \text { sediment }}$



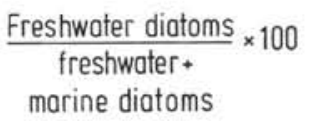

marine diatoms

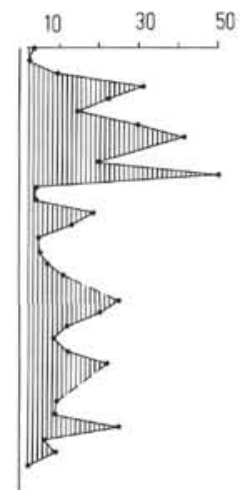

Freshwater diatoms + $\log \frac{\text { phytoliths }+ \text { pollen }}{\text { g sediment }}$

Figure 7. Enlarged plot for the upper $70 \mathrm{~cm}$ of Hole $880 \mathrm{~A}$ showing the abundance of vesicular ash $>20 \mu \mathrm{m}$, marine diatoms, and eolian transported freshwater diatoms, phytoliths, and pollen. All are plotted on a logarithmic scale versus the ratio of freshwater to marine diatoms.

Table 7. Abundance of major siliceous microfossil groups, zeolites, and $\mathrm{CH}_{3} \mathrm{COOH}$-insoluble residue $>2 \mu \mathrm{m}$ in samples from $\mathrm{Hole} 871 \mathrm{~A}$.

\begin{tabular}{|c|c|c|c|c|c|c|c|c|}
\hline $\begin{array}{l}\text { Core, section, } \\
\text { interval }(\mathrm{cm})\end{array}$ & $\begin{array}{c}\text { Depth } \\
\text { (cm bsf) }\end{array}$ & $\begin{array}{c}\mathrm{CH}_{3} \mathrm{COOH}- \\
\text { insoluble residue } \\
(\%)\end{array}$ & Archaeomonadaceae & $\begin{array}{l}\text { Siliceous } \\
\text { sponge } \\
\text { spicules }\end{array}$ & Radiolarians & Silicoflagellates & Diatoms & $\begin{array}{l}\text { Log zeolite } \\
\text { crystals per } \\
\text { gram sediment }\end{array}$ \\
\hline \multicolumn{9}{|l|}{$144-871 \mathrm{~A}-$} \\
\hline IH-I, $41-43$ & $41-43$ & 0.4 & 2.8 & 3.8 & 4.1 & 2.0 & 3.3 & - \\
\hline $1 \mathrm{H}-1,87-91$ & $87-91$ & 0.5 & 2.9 & 3.4 & 2.9 & - & 2.7 & - \\
\hline $\mathrm{IH}-2,41-43$ & $191-193$ & 0.6 & - & 3.0 & 2.0 & - & 2.0 & 3.0 \\
\hline $1 \mathrm{H}-2.87-91$ & $237-241$ & 0.7 & - & 3.4 & 1.8 & - & - & 2.4 \\
\hline $1 \mathrm{H}-3,41-43$ & $341-343$ & 0.8 & - & 3.1 & 1.7 & - & - & 3.2 \\
\hline $1 \mathrm{H}-3,74-78$ & $374-378$ & 0.5 & - & 3.5 & 1.7 & - & - & 2.3 \\
\hline $1 \mathrm{H}-3,148-150$ & $448-450$ & 0.6 & 2.9 & 2.7 & 1.4 & - & - & 5.2 \\
\hline IH $-4,14-18$ & $464-468$ & 0.5 & $=$ & 3.1 & - & - & - & 5.5 \\
\hline $1 \mathrm{H}-4,39-41$ & $489-491$ & 0.5 & - & 2.5 & - & - & - & 5.7 \\
\hline $1 \mathrm{H}-4,12 \mathrm{l}-123$ & $571-573$ & 0.5 & 1.9 & 2.5 & 1.2 & - & - & 6.0 \\
\hline $1 \mathrm{H}-5,75-79$ & $675-679$ & 0.4 & - & 1.7 & - & - & - & 5.8 \\
\hline $\mathrm{IH}-\mathrm{CC}$ & 745 & 0.6 & 1.9 & 1.5 & 1.0 & - & - & 6.0 \\
\hline
\end{tabular}

Note: Major siliceous microfossil group values calculated as log siliceous microfossil group per gram sediment.

Table 8. Abundance of major siliceous microfossil groups, zeolites, and $\mathrm{CH}_{3} \mathrm{COOH}$-insoluble residue $>2 \mu \mathrm{m}$ in samples from $\mathrm{Holes} 872 \mathrm{~A}$ and $872 \mathrm{C}$.

\begin{tabular}{|c|c|c|c|c|c|c|c|c|}
\hline $\begin{array}{l}\text { Core, section, } \\
\text { interval }(\mathrm{cm})\end{array}$ & $\begin{array}{c}\text { Depth } \\
\text { (cm bsf) }\end{array}$ & $\begin{array}{c}\mathrm{CH}_{3} \mathrm{COOH}- \\
\text { insoluble residue } \\
(\%)\end{array}$ & Archaeomonadaceae & $\begin{array}{l}\text { Siliceous } \\
\text { sponge } \\
\text { spicules }\end{array}$ & Radiolarians & Silicoflagellates & Diatoms & $\begin{array}{l}\text { Log zeolite } \\
\text { crystals per } \\
\text { gram sediment }\end{array}$ \\
\hline \multicolumn{9}{|l|}{$144-872 \mathrm{~A}$ - } \\
\hline IH-I (top) & $0-4$ & 0.3 & - & - & - & - & - & 4.8 \\
\hline IH- $1,39-43$ & $39-43$ & 0.5 & 2.3 & 2.9 & 2.9 & - & 2.4 & - \\
\hline $1 \mathrm{H}-1,89-93$ & $89-93$ & 0.5 & 2.0 & 2.4 & 2.4 & - & 1.7 & 2.6 \\
\hline $1 \mathrm{H}-1,140-144$ & $140-144$ & 0.5 & 2.4 & 2.4 & 1.8 & - & 2.3 & 2.8 \\
\hline $\mathrm{IH}-2,39-43$ & $189-193$ & 0.4 & 2.0 & 2.0 & 2,4 & - & - & 3.7 \\
\hline IH-2, 89-93 & $239-243$ & 0.3 & 1.6 & 1.9 & - & - & - & 4.4 \\
\hline $1 \mathrm{H}-2,140-144$ & $290-294$ & 0.6 & - & - & 1.2 & - & - & 3.8 \\
\hline IH-3, 39-43 & $339-343$ & 0.4 & 2.1 & - & - & - & - & 4.1 \\
\hline $\mathrm{IH}-3,89-93$ & $389-393$ & 0.3 & 2.1 & - & - & - & - & 4.3 \\
\hline IH-3, 140-144 & $440-444$ & 0.3 & - & - & - & & 1.0 & 4.0 \\
\hline $1 \mathrm{H}-4,39-43$ & $489-493$ & 0.3 & 2.0 & - & - & - & - & 4.8 \\
\hline IH-4. 89-93 & $539-543$ & 0.3 & 2.0 & - & - & - & - & 4.6 \\
\hline $1 \mathrm{H}-4,140-144$ & $590-594$ & 0.2 & 1.8 & - & - & - & - & 4.9 \\
\hline IH $-5,39-43$ & $639-643$ & 0.3 & 2.3 & - & - & - & - & 4.3 \\
\hline $1 \mathrm{H}-5,89-93$ & $689-693$ & 0.1 & 1.9 & - & - & - & 1.1 & 4.4 \\
\hline $\mathrm{IH}-\mathrm{CC}$ & 745 & 0.4 & 2.4 & - & - & - & - & 5.1 \\
\hline \multicolumn{9}{|l|}{$144-872 \mathrm{C}$ - } \\
\hline $1 \mathrm{H}-1,0-10$ & $0-10$ & 0.4 & 2.7 & 2.6 & 2.8 & - & 1.7 & 2.7 \\
\hline $1 \mathrm{H}-1,16-20$ & $16-20$ & 0.6 & 2.2 & 2.7 & 2.8 & - & 2.0 & 2.4 \\
\hline $1 \mathrm{H}-1,36-42$ & $36-42$ & 0.6 & 3.2 & 2.8 & 3.1 & - & 1.9 & 3.2 \\
\hline $1 \mathrm{H}-1,52-56$ & $52-56$ & 0.5 & 2.8 & 2.5 & 2.9 & - & 2.4 & 2.7 \\
\hline IH-I, 75-79 & $75-79$ & 0.4 & 2.6 & 2.4 & 2.6 & - & 2.0 & 2.7 \\
\hline $1 \mathrm{H}-1,90-94$ & $90-94$ & 0.7 & 3.1 & 2.7 & 2.1 & - & 1.2 & 2.8 \\
\hline
\end{tabular}

Note: Major siliceous microfossil group values calculated as log siliceous microfossil group per gram sediment. 


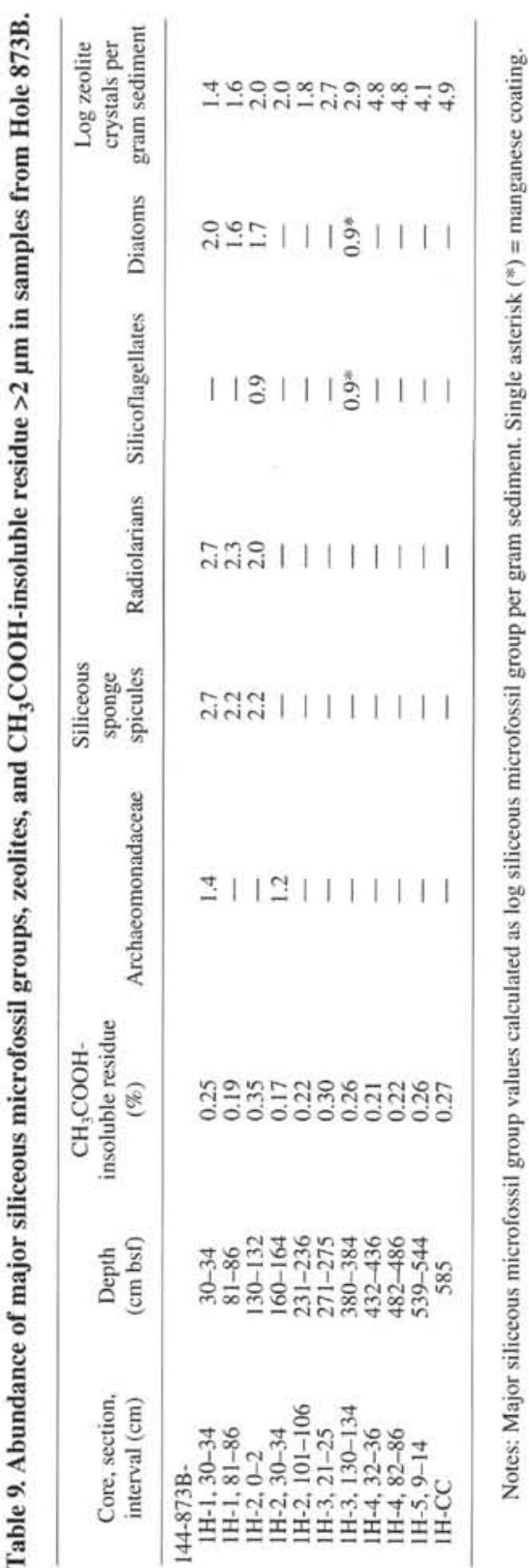

freshwater diatoms shows strong fluctuations down to $15 \mathrm{~m}$ core depth (Figs. 5, 6), therefore, throughout the Quaternary represented in this hole.

\section{Siliceous Sponge Spicules}

Many different types of sponge spicules, microscleres, and macroscleres were found in the upper Quaternary sediments (Pls. 2 and 3). The nomenclature used here follows Wiedenmayer (1977). A documentation of the types of siliceous sponge spicules from sediments on top of guyots is of special interest because it provides information on which species of sponges live in this region at water depths between 1000 and $1500 \mathrm{~m}$. On continental slopes, downslope transport from environments such as reefs can distort the depth distribution; however, on a freestanding guyot, the admixture of allochthonous material from shallower environments is not of concern. For the Eocene to the Pleistocene, Ivanik (1983) and McCartney (1990) documented sponge spicules from deep-sea sediments deposited in similar locations on seamounts or submarine plateaus (Maurice Ewing Bank, Maud Rise). Deep-sea sponge studies containing a description of spicules include Schulze (1899), Lévi (1964), and Tendal (1973). Oxea, strongyle, style, acanthostrongyle, acanthooxea, acanthostyle, tylostyle, and microrhabd were dominant among the microscleres. The microsclere type sigma was also found relatively frequently as were isochele, spheraster, euaster, and fragments of fibroreticulate skeletons of hexactinellids. Tetraxons such as calthrops or oxyhexaster were very rare as were the microsclere types of hexactinellids (such as pinule and scropule).

\section{Diatoms}

\section{Sites 871 and 878}

On the three western Pacific guyots in the tropical-subtropical region between $5^{\circ} \mathrm{N}$ and $12^{\circ} \mathrm{N}$, the diversity of diatoms is very low and the abundance is scarce (Tables 2-4). At Site $878\left(27^{\circ} 19.14^{\prime} \mathrm{N}\right)$, diversity is slightly higher (Table 5). At Sites $871,872,873$, and 878 , the relatively dissolution-resistant and geographically widely distributed species Thalassiothrix longissima, Azpeitia nodulifer, A. neocrenulata, Thalassionema nitzschioides, and Nitzschia marina are most commonly found, as well as fragments of Ethmodiscus sp., and sporadic Rhizosolenia bergonii, Cyclotella litoralis, Hemidiscus cuneiformis, and Chaetoceros messanensis. Some of these are illustrated on Plates 1 and 4.

Species that are predominantly tropical-subtropical, such as Asteromphalus sacrophagus forma obovatus, and also A. elegans, A. hiltonianus, and Asterolampra marylandica, occur only rarely.

Also, species that have a wider latitudinal range but which prefer more fertile waters, such as Roperia tesselata, Nitzschia bicapitata, $N$. interruptestriata, Asteromphalus hookeri, and Thalassiosira species, occur only sporadically at these western Pacific open-ocean locations.

No stratigraphic determination based on diatoms was possible at these sites because of the few species present and the absence of Fragilariopsis doliolus, the name-giving species for the uppermost diatom zone for the low latitudes.

\section{Site 880}

On Takuyo-Daisan (Site 880), at approximately $34^{\circ} \mathrm{N}$, the situation is quite different. This site lies within the area of increased planktonic primary productivity (see Koblentz-Mishke et al., 1970). Here, diatom abundance in the upper Quaternary sediments fluctuates between $10^{4}$ to $10^{6}$ valves per gram sediment (Figs. 5, 7; Table 11). The more dissolution-resistant valves such as Xanthiopyxis sp. and other resting spore types commonly dominate the assemblages. Valves of Thalassiothrix longissima, Thalassionema nitzschioides, $T$. nitzschioides var. parva. Thalassiosira oestrupii, Cyclotella litoralis, and Chaetoc- 
Table 10. Abundance of major siliceous microfossil groups, zeolites, and $\mathrm{CH}_{3} \mathrm{COOH}$-insoluble residue $>2 \mu \mathrm{m}$ in samples from Hole $878 \mathrm{~A}$.

\begin{tabular}{|c|c|c|c|c|c|c|c|c|}
\hline $\begin{array}{l}\text { Core, section, } \\
\text { interval }(\mathrm{cm})\end{array}$ & $\begin{array}{c}\text { Depth } \\
\text { (cm bsf) }\end{array}$ & $\begin{array}{c}\mathrm{CH}_{3} \mathrm{COOH}- \\
\text { insoluble residue } \\
(\%)\end{array}$ & Archaeomonadaceae & $\begin{array}{l}\text { Siliceous } \\
\text { sponge } \\
\text { spicules }\end{array}$ & Radiolarians & Silicoflagellates & Diatoms & $\begin{array}{l}\text { Log zeolite } \\
\text { crystals per } \\
\text { gram sediment }\end{array}$ \\
\hline \multicolumn{9}{|l|}{$144-878 \mathrm{~A}-$} \\
\hline IR (top) & $0-1$ & 17.78 & 3.8 & - & 3.1 & 3.1 & 3.8 & 7.0 \\
\hline IR-1, 12-14 & $12-14$ & 21.79 & 2.5 & 3.3 & - & - & 3.5 & 6.3 \\
\hline IR-1, $93-95$ & $93-95$ & 32.03 & 3.3 & - & - & - & 2.9 & 6.8 \\
\hline IR-2, $21-23$ & $171-173$ & 21.10 & 4.0 & - & - & - & - & 6.9 \\
\hline IR-2, 71-73 & $221-223$ & 20.08 & 3.7 & 2.3 & - & - & - & 6.9 \\
\hline IR-2, 108-110 & $258-260$ & 14.14 & 3.1 & - & - & - & - & 6.9 \\
\hline IR-3, 2I-23 & $321-323$ & 16.61 & - & - & - & - & - & 7.1 \\
\hline IR- $3,35-37$ & $335-337$ & 16.31 & 3.0 & - & - & - & - & 7.0 \\
\hline IR-CC & $350-352$ & 21.26 & 3.1 & - & - & - & - & 7.0 \\
\hline
\end{tabular}

Note: Major siliceous microfossil group values calculated as log siliceous microfossil group per gram sediment.

\section{Sites}


Figure 8. Latitudinal plot of selected parameters for two different time intervals in the Quaternary: the late Quaternary Emiliania huxleyi Zone, and the early Quaternary Helicosphaera selli to Calcidiscus macintyrei Zone. A. Abundance of diatom valves per gram sediment (logarithmic scale). B. Percent of $\mathrm{CH}_{3} \mathrm{COOH}$-insoluble residue $>2 \mu \mathrm{m}$ of the bulk sediment. C. Downcore occurrence of diatoms plotted vs. age. The age assignment is based on the calcareous nannofossil stratigraphy (Premoli Silva, Haggerty, Rack, et al., 1993; see also various papers in this volume). The hatched part of the columns represents a hiatus. D. Downcore occurrence of diatoms plotted vs. depth. eros messanensis, among others, can be common to frequent. The diversity at Site 880 is relatively high, reaching as many as 33 species per 100 counted specimens (Table 6). Overall, the assemblages have a temperate character. Sporadically, a fragment or valve of a preferably tropical-subtropical species such as Asteromphalus elegans or Asterolampra marylandica occurs. But cosmopolitan and temperate species are dominant. The presence of temperate endemic northern Pacific species such as Neodenticula kamtschatica and $N$. seminae is quite conspicuous, as are the presence of species characteristic for higher productivity shelf and shelf-edge environments, such as Cyclotella litoralis, species of the genus Chaetoceros, Nitzschia bicapitata, Odontella aurita, Stephanopyxis turris, and Paralia sulcata.

Concerning the biostratigraphy based on diatoms, the Neodenticula seminae Zone and the Rhizosolenia curvirostris Zone can be identified within the upper $7 \mathrm{~m}$ of the cores (Table 6). The boundary between the two zones lies between Samples 144-880A-1H-1, $62 \mathrm{~cm}$, and $-1 \mathrm{H}-1,64 \mathrm{~cm}$. It was determined using the last occurrence of Thalassiosira nidulus (0.28-0.39 Ma; Barron, 1992). The marker species Simonseniella curvirostris is absent from the samples studied. The base of the R. curvirostris Zone cannot be determined because the diatom preservation below $7 \mathrm{~m}$ is too poor.

Some reworking of older material was also found at Site 880. Single valves of early Oligocene (Pyxilla reticulata), Miocene (Denticulopsis lauta), and early Pliocene (Rossiella tatsunokuchiensis) diatom species were encountered in different samples (Table 6).

\section{Latitudinal Trends}

Tracing latitudinal trends is complicated by the fact that, because of erosion or sediment loss during coring, the uppermost Quaternary stratigraphic intervals are not represented at some sites. For example, the Emiliania huxleyi Acme Zone, within which the best preserved siliceous microfossil assemblages can be expected, was recovered only at Sites 871 and 880; at Sites 873 and 878 no upper Quaternary sediments were recovered. Nevertheless, for two stratigraphic intervals of the Quaternary, a south-north comparison was possible: (1) for the Emiliania huxleyi Zone, which was cored at Sites 871, 872, and 880; and (2) for the Helicosphaera sellii to Calcidiscus macintyrei zones, an interval recovered at Sites $871,872,873,878$, and 880 .

Diatom abundance is low at the three southern subtropical sites, and their preservation is poor. Their abundance (Fig. 8) increases by approximately 1 order of magnitude at about $27^{\circ} \mathrm{N}$, on MIT Guyot (Site 878 ), and by up to 3 orders of magnitude at the northernmost site, on Takuyo-Daisan Guyot (Site 880 ). Here diatoms are better preserved and a higher diversity of their assemblages is found (Table 6). Unfortunately, at this site, the base of diatom occurrence cannot be determined because Hole 880 was drilled only $18 \mathrm{~m}$ into the upper Pliocene. Diatoms are still present at that depth, although at a lower diversity, and it is the more dissolution-resistant species that occur at these core depths. 
Table 11. Logarithmic abundance of major siliceous microfossil groups, pollen, and vesicular ash, and percent abundance of $\mathrm{CH}_{3} \mathrm{COOH}$-insoluble residue $>2 \mu \mathrm{m}$ in samples from Hole $880 \mathrm{~A}$.

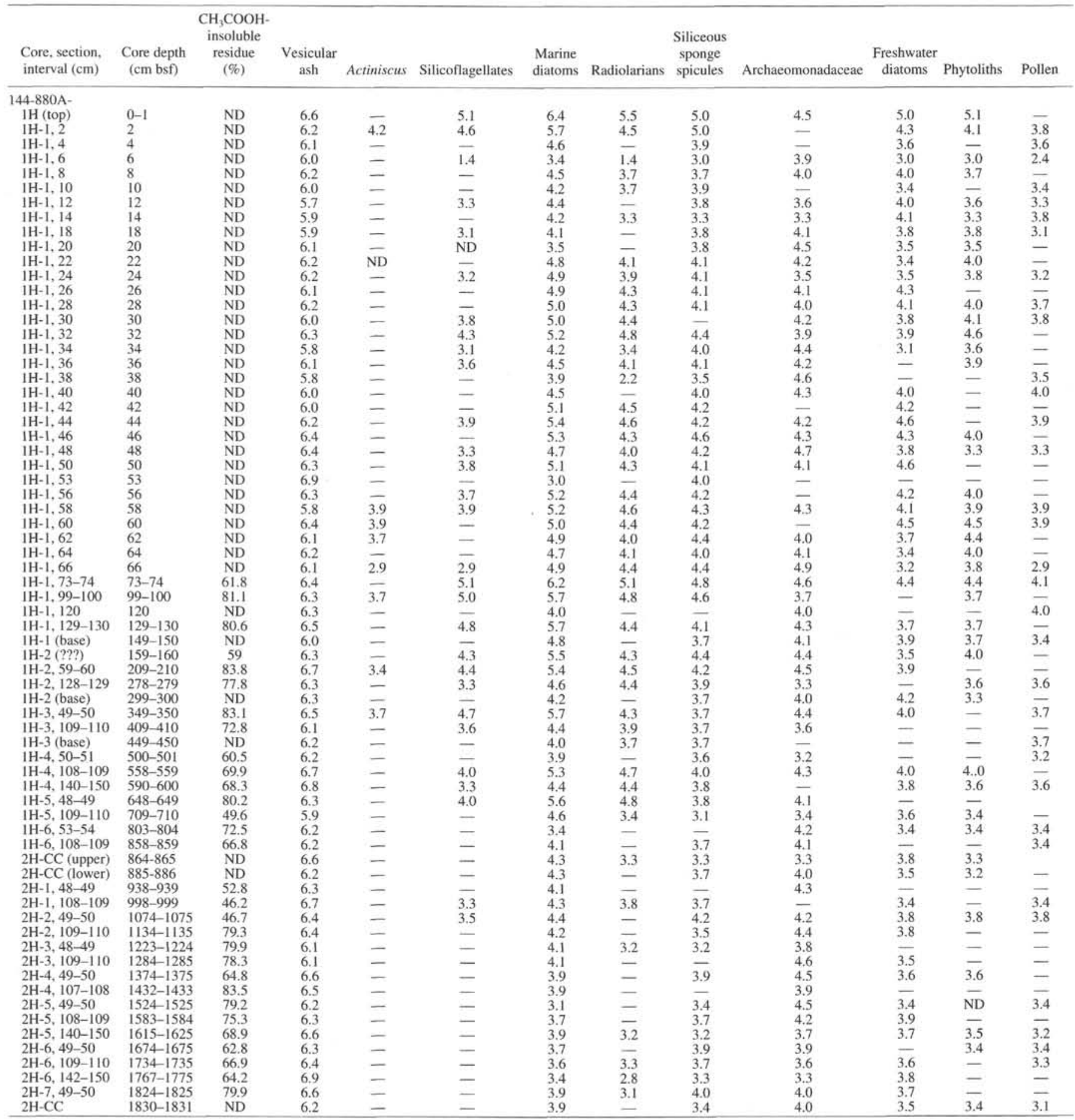

Note: $\mathrm{ND}=$ not determined.

A correlation of diatom abundance (Fig. 8A) and preservation with the amount of $\mathrm{CH}_{3} \mathrm{COOH}$-insoluble residue $>2 \mu \mathrm{m}$ (Fig. 8B) and an inverse correlation with the calcium carbonate content of the sediment can be recognized.

The $\mathrm{CH}_{3} \mathrm{COOH}$-insoluble residue predominantly consists of wind-transported volcanic ash. Its amount in the highly calcareous, tropical-subtropical, Quaternary pelagic sediments is minimal. At approximately $27^{\circ} \mathrm{N}$, ash content fluctuates during the early Quaternary around $20 \%$, and around $70 \%$ (between $40 \%$ and $90 \%$ ) at approximately $34^{\circ} \mathrm{N}$. Such quantities, especially if it is vesicular ash as at Site 880 , can influence the preservation of biogenic silica, although the higher clay content possibly plays a role as well.

Another influential factor is the increased primary productivity at these two northern locations, especially off Japan (Koblentz-Mishke et al., 1970). That productivity at Site 880 is higher than at the other sites drilled further south is shown (1) by the fact that, in addition to 
an increase in Pleistocene sedimentation rates (at Sites 871-873, they lie between $I$ and $10 \mathrm{~m} / \mathrm{m}$.y. and at Site 880 between 10 and $20 \mathrm{~m} /$ m.y.; cf. Erba, this volume) within these sediments, the abundance of planktonic marine diatoms increases up to 3 orders of magnitude from the southern sites to Site 880; and (2) by the presence of Spermatogonia sp. and Actiniscus sp. (Table 6), which also indicates more fertile surface waters. The increased primary productivity in this region was also illustrated by the frequency of fishing boats met during the cruise: none were seen until we approached Takuyo-Daisan. In addition, the benthic life on this guyot is relatively rich. On the more southern guyots, no macroorganisms were seen with the camera, only barren rock or pelagic sediments in part with ripples on the surface. On Takuyo-Daisan, the camera showed corals, sponges, and possibly crinoids. Such benthic life is proof that sufficient nutrients are reaching the seafloor.

If one plots the age of the sediment obtained from calcareous nannofossil stratigraphy (Premoli Silva, Haggerty, Rack, et al., 1993) down to which diatoms were found at each site, the result is that the lowest occurrence of diatoms in the sediments is increasingly older toward the north (Fig. 8C). However, because a stratigraphic interval is missing at the top of the subtropical sites, the core depth down to which diatoms are preserved within these sites does not show such a clear trend (Fig. 8D).

Pore-water analysis suggests that bottom-water concentrations perpetuate throughout the sandy foraminifer-nannofossil oozes of the pelagic cap sediments and no special conditions in the near-surface sediments can be recognized.

\section{SUMMARY}

The siliceous microfossil assemblages at all of the Leg 144 sites studied are influenced by silica dissolution and diagenesis. This influence is especially severe in the highly calcareous sediments of the tropical-subtropical pelagic sediments. It is weakest in the less calcareous pelagic sediments off Japan, where vesicular ash constitutes a major component of the sediment and may help to protect siliceous microfossils from dissolution, and where the accumulation rates of biosiliceous components are higher.

The types of siliceous sponge spicules from desmospongia and hexactinellid sponges living on the guyots, in water depths of 1000 $1500 \mathrm{~m}$, are documented.

Only at Site 880 , on Takuyo-Daisan Guyot off Japan, are the preservation and diversity within the diatom assemblages sufficient to allow determination of the diatom biostratigraphic zones established for the North Pacific. The last occurrence datum of Thalassiosira nidulus indicates that the upper $62 \mathrm{~cm}$ of the Neogene pelagic sediments would belong to the Neodenticula seminae Zone and the sediments below, down to $7 \mathrm{~m}$, to the Rhizosolenia curvirostris Zone.

In spite of the poor preservation of diatoms in most samples analyzed, geographical restrictions of some species were evident. For example, Asteromphalus sacrophagus var. obovatus was only found at the southernmost location (Site 871), whereas Neodenticula seminae and $N$. kamtschatica occur persistently only at the northernmost site (880) and with single sporadic occurrences at Hole 872A.

The increase of diatom abundance from the three sites at $5-15^{\circ} \mathrm{N}$, where it is low, to higher values at $27^{\circ} \mathrm{N}$ and even higher at $34^{\circ} \mathrm{N}$, off Japan, is largely a result of higher primary productivity in the belt influenced by west winds.

The abundance of freshwater diatoms, phytoliths, and pollen as well as of vesicular ash on Takuyo-Daisan Guyot document a high eolian component in the pelagic sediments east of Japan. Close sample spacing from the upper $70 \mathrm{~cm}$ recovered at Hole $880 \mathrm{~A}$ allows the recognition of climate-related changes in abundance of siliceous microfossils. Because these abundance changes show the same trend as the abundance of volcanic ash, dilution by windblown terrigenous components and possibly preservational effects are thought to be responsible for the abundance changes.

\section{TAXONOMIC REFERENCES FOR MARINE DIATOM SPECIES}

In the following, all diatom species are listed with reference either to the original or to a more modern description that was used as a basis for species determination in this study. A few remarks are made only where species determination is not unanimously handled in the recent literature, and only those species are illustrated on Plate 1.

$$
\begin{gathered}
\text { Genus Actinocyclus Ehrenberg (1837) } \\
\text { Actinocyclus curvatulus Janisch in Schmidt (1878) } \\
\text { Pl. 1, Fig. } 7
\end{gathered}
$$

Description. A. Schmidt (1874-1900), pl. 57, fig. 31

Remarks. The valves are convex. The areolae decrease in size toward the margin and form segments, the longest ray of each being clearly curved.

$$
\text { Actinocyclus ellipticus Grunow in Van Heurck (1883) }
$$

Description. Van Heurck (1883), pl. 124, fig. 10; Hustedt (1930), p. 533, fig. 303

Actinocyclus ingens Rattray forma planus Whiting et Schrader (1985)

Description. Whiting and Schrader (1985), p. 74, pl. 3, fig. 12 Actinocyclus octonarius Ehrenberg (1838)

Description. Ehrenberg (1838), p. 173, pl. 21, fig. 7; Hendey (1964), p. 83 , pl. 24 , fig. 3

Actinocyclus tenellus (Brébisson) Andrews (1976)

Description. Andrews (1976), p. 14, pl. 3, figs. 8, 9

$$
\text { Actinocyclus sp. } 1
$$$$
\text { Pl. 1, Fig. } 6
$$

Description. The valve outline is round. The valve face is flat and densely covered with areolae arranged in fascicles and slightly decreasing in size from the center $(10-14$ areolae in $10 \mu \mathrm{m})$ toward the margin $(12-16$ areolae in 10 $\mu \mathrm{m})$. There are 7-8 marginal labiate processes. They are located at the end of the longest row of each fascicle. The areolae on the mantle are small (approximately 15 in $10 \mu \mathrm{m}$ ) and arranged in a dense quincunx pattern, distinctly offset from the pattern on the valve face.

Genus Actinoptychus Ehrenberg (1841) Actinoptychus senarius (Ehrenberg) Ehrenberg (1838)

Description. Hendey (1964), p. 95, pl. 23, figs. 1-2 Actinoptychus splendens (Shadboldt) Ralfs in Pritchard (1861)

Description. Hustedt (1930), p. 478, fig. 265 Genus Asterolampra Ehrenberg (1845) Asterolampra marylandica Ehrenberg (1845)

Description. Ehrenberg (1845), p. 76, fig. 10

Genus Asteromphalus Ehrenberg (1845)

Asteromphalus elegans Greville (1859)

Description. Greville (1859), p. 161, pl. 7, fig. 6

Asteromphalus hiltonianus (Greville) Ralfs in Pritchard (1861) 15

Description. Pritchard (1861), p. 837; Greville (1860), p. 117, pl. 4, fig. Asteromphalus hookeri Ehrenberg (1844c)

Description. Ehrenberg (1845), pl. 35A/21, fig. 2 Asteromphalus ornithopus Karsten (1907) Pl. 4, Fig. 6

Description. Karsten (1907), p. 90, pl. 8, fig. 13 Asteromphalus robustus Castracane (1875)

Description. Castracane (1875), p. 393 , pl. 6, fig. 5 
Asteromphalus sarcophagus Wallich forma obovatus Thorington-Smith (1970)

Description. Thorington-Smith (1970), pp. 821-822, pl. 1, fig. 3

Asteromphalus sarcophagus Wallich forma sarcophagus Thorington-Smith (1970)

Description. Thorington-Smith (1970), pp. 820-821, pl. 1, fig. 1

Genus Aulacoseira Thwaites (1848)

$$
\text { Pl. 2, Fig. } 20
$$

Remark. The species within this genus all are freshwater species and were not determined to the species level.

Genus Azpeitia M. Peragallo in Tempère et Peragallo (1912)

Azpeitia africana (Janisch ex Schmidt) Fryxell et Watkins (1986)

32

Description. Fryxell, Sims, and Watkins (1986), pp. 22-23, figs. 22-23,

Azpeitia neocrenulata (Van Landingham) Fryxell et Watkins (1986)

Description. Fryxell, Sims, and Watkins (1986), pp. 18-19, figs. 16, 30 Azpeitia nodulifer (Schmidt) Fryxell et Sims (1986) 30

Description. Fryxell, Sims, and Watkins (1986), pp. 19-20, figs. 17, 18,

$$
\text { Azpeitia tabularis (Grunow) Fryxell et Sims (1986) }
$$

Description. Grunow (1884), p. 86; Fryxell, Sims, and Watkins (1986), pp. 16-18, figs. $14-15,30$

$$
\begin{gathered}
\text { Genus Bacteriastrum Shadbolt (1854) } \\
\text { Bacteriastrum sp. }
\end{gathered}
$$

Remark. The only valve found (at Site 880 ) is incomplete. No species determination was possible.

\section{Genus Chaetoceros Ehrenberg (1844a)}

Chaetoceros messanensis Castracane (1875)

PI. 1, Fig. 1

Description. Castracane (1875), p. 394, pl. 1, fig. 1a; Hustedt (1920), pl. 322, figs. $4,7 \mathrm{c} ;$ pl. 325 , fig. 3

\section{Chaetoceros $\mathrm{sp}$.}

Remark. Relatively robust valve fragments of other Chaetoceros species with the setae generally broken above their basal part were found sporadically but were not determined to the species level.

$$
\begin{gathered}
\text { Genus Cocconeis Ehrenberg (1838) } \\
\text { Cocconeis placentula Ehrenberg (1838) } \\
\text { Pl. 2, Fig. } 19
\end{gathered}
$$

Description. Ehrenberg (1841), pl. 1/1, fig. 10, pl. 1/2, fig. 24; Hustedt (1933), p. 347 , fig. $802 a-b$

$$
\begin{aligned}
& \text { Genus Coscinodiscus Ehrenberg (1838) } \\
& \text { Coscinodiscus argus Ehrenberg (1839) }
\end{aligned}
$$

Description. Hasle and Sims (1986b), pp. 308-310, 312, 316, figs. 1-7, $33-34$

$$
\text { Coscinodiscus gigas Ehrenberg (1841) }
$$

Description. Ehrenberg (1854), pl. 18, fig. 34.

$$
\text { Coscinodiscus marginatus Ehrenberg (1841) }
$$

Description. Ehrenberg (1841), p. 142; Ehrenberg (1854), pl. 18, fig. 44, pl. 33 , figs. $12-13$, pl. $38 \mathrm{~B} / 22$, fig. 8

Coscinodiscus pacificus (Grunow) Rattray (1890)

$$
\text { Pl. 4, Fig. } 1
$$

Description. Rattray (1890), p. 563

$$
\begin{gathered}
\text { Coscinodiscus radiatus Ehrenberg (1840) } \\
\text { Pl. 1, Fig. } 8
\end{gathered}
$$

Description. Hasle and Sims (1986a), pp. 310-314, 317, figs. 8-32, 35-

Genus Cyclotella Kützing (1833)

Cyclotella litoralis Lange et Syvertsen (1989)

$$
\text { Pl. 1, Figs. 2-3 }
$$

Description. Lange and Syvertsen (1989), pp. 343-346, figs. 1-30

Cyclotella radiosa (Grunow) Lemmermann (1900)

$$
\text { P1. 2, Fig. } 22
$$

Description. Round and Håkansson (1992), pp. 114-116, figs. 9-12, 16, 32-35

Remark. C. radiosa is a freshwater species

Genus Denticulopsis Simonsen (1979)

Denticulopsis lauta (Bailey) Simonsen (1979)

$$
\text { Pl. 1, Fig. } 12
$$

Description. Yanagisawa and Akiba (1990), pp. 235-236, pl. 2, figs. 68,15 ; pl. 5 , figs. $1-3$; pl. 9 , fig. 1

Genus Diploneis Ehrenberg (1840)

Diploneis bombus Ehrenberg (1844b)

$$
\text { Pl. 4, Fig. } 4
$$

Description. Hustedt (1959), pp. 704-709, fig. 1086.

$$
\text { Genus Ethmodiscus Castracane (1866) }
$$

Remarks. As only relatively small fragments of Ethmodiscus valves were found no attempt was made to determine the species.

Genus Fragilariopsis Hustedt (1913) in A. Schmidt (1874-1900)

Fragilariopsis doliolus (Wallich) Medlin et Sims (1993)

Description. Medlin and Sims (1993), p. 332, figs. 5-12

Genus Hemidiscus Wallich (1860)

Hemidiscus cuneiformis Wallich (1860)

Description. Wallich (1860), p. 42, pl. 2, figs. 3-4; Hustedt (1930), p. 904, fig. 542e; Fryxell, Sims, and Watkins (1986), p. 25, fig. 26

\section{Hemidiscus cuneiformis Wallich var.}

$$
\text { Pl. 1, Fig. } 17
$$

Remark. This variety differs from the species by its nearly elliptical shape and the much finer areolation.

\section{Hemidiscus sp. 1}

Pl. 1, Fig. 5

Description. This species is similar in shape to Hemidiscus karstenii Jousé in Jousé et al. (1962), but differs from it because of its finer and denser areolation. Also, the size of the areolae decreases only slightly from the valve center toward the margin.

Genus Navicula Bory (1822)

Navicula directa (Wm. Smith) Ralfs in Pritchard (1861)

Description. Hendey (1964), p. 202; A. Schmidt (1874-1900), pl. 47, fig. 5

Genus Neodenticula Akiba et Yanagisawa (1986)

Neodenticula kamtschatica (Zabelina) Akiba et Yanagisawa (1986) Pl. 1, Figs. 19-21

Description. Yanagisawa and Akiba (1990), pp. 259-261, pl. 7, figs. 27-37

Neodenticula seminae (Simonsen et Kanaya) Akiba et Yanagisawa (1986) PI. 1, Figs. 13-15 49

Description. Yanagisawa and Akiba (1990), pp. 263-264, pl. 7, figs. 45-

Genus Nitzschia Hassall (1845)

Nitzschia bicapitata Cleve (1900)

Description. Cleve 1900, p. 933 , fig. 12

Nitzschia braarudii Hasle (1960)

Description. Hasle (1960), p. 22, pl. 7, figs. 58-63

\section{Nitzschia interruptestriata Simonsen (1974)}

Pl. 1, Fig. 11 $1-7$

Description. Simonsen (1974), p. 52, pl. 36, figs. 9-11; pl. 37, pl. 38, figs.

Nitzschia kolaczekii Grunow (1867)

Description. Grunow (1877), p. 173, pl. 194, fig. 10

Nitzschia marina Grunow in Cleve and Grunow (1880)

Description. Grunow in van Heurck (1881), pl. 57, figs. 26-27 
Nitzschia sicula (Castracane) Hustedt (1958)

Description. Hustedt (1958), p. 180

Genus Odontella Agardh (1832)

Odontella aurita Agardh (1832)

Description. Hustedt (1930), pp. 846-849, fig. 501

Genus Paralia Heiberg (1863)

Paralia sulcata (Ehrenberg) Cleve (1873)

Description. Hustedt (1930), pp. 276-279, figs. 118-120

Genus Planktoniella Schütt (1893)

Planktoniella sol (Wallich) Schütt (1893)

Pl. 4, Fig. 3

Description. Gerloff (1970), pp. 203-215

Genus Pseudotriceratium Grunow (1884)

Pseudotriceratium cinnamomeum (Greville) Grunow (1884)

Pl. 1, Fig. 4

Description. Grunow (1884), p. 83; Greville (1863), p. 232, pl. 9, fig. 12

Genus Pyxilla Greville (1865)

Pyxilla reticulata Grove et Sturt (1887)

Description. Fenner (1985), pp. 735-736, pl. 11, figs. 6-10

Remark. The fragment found at Site 880 must be reworked from Paleogene sediments, probably lower Oligocene.

\section{Resting Spore \\ Pl. 4, Fig. 7}

Remark. As resting spores of diatoms were found only relatively rarely, only two groups were differentiated, the Xanthiopyxis type resting spores and other resting spores. But they were not determined to the species level.

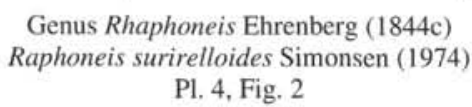

Description. Simonsen (1974), pp. 35-36, pl. 23, figs. 2-8

Genus Rhizosolenia Ehrenberg (1841)

Rhizosolenia bergonii H. Peragallo (1892)

Description. Hustedt (1930), pp. 575-577, fig. 327

Rhizosolenia hebetata Bailey (1856)

Description. Grunow (1884), p. 44, pl. 5, figs. 48-50

Rhizosolenia setigera Brightwell (1858)

Description. van Heurck (1880-1885), p. 194, pl. 78, figs. 6-8

Rhizosolenia styliformis Brightwell (1858)

Description. van Heurck (1880-1885), p. 194, pl. 78, figs. 1-5; pl. 79 , figs. 1-2

Rhizosolenia styliformis var. longispina Hustedt (1914)

Description. Hustedt (1914), pl. 316, figs. 5-7, 12; Hustedt (1930), p. 586, fig. 334

Genus Roperia Grunow in van Heurck (1883)

Roperia tesselata (Roper) Grunow in van Heurck (1883)

Description. Fryxell, Sims, and Watkins (1986), p. 24, fig. 25

Genus Rossiella Desikachary et Maheshwari (1958)

Rossiella tatsunokuchiensis (Koizumi) Gersonde et Schrader (1984)

Description. Koizumi (1972), p. 349, pl. 42, figs. 3-4

Genus Rouxia Brun et Héribraud in Héribraud (1893)

Rouxia californica M. Peragallo in Tempere and Peragallo (1910)

Description. Tempère and Peragallo (1910), p. 245, nos. 468-469

Genus Simonseniella Fenner (1991)

Simonseniella barboi (Brun) Fenner (1991) $1-2$

Synonym. Proboscia barboi (Brun) Jordan and Priddle (1991), p. 56, figs.

Description. Fenner (1991), p. 108, pl. 3, figs. 1, 3
Genus Stellarima Hasle et Sims (1986a)

Stellarima microtrias (Ehrenberg) Hasle et Sims (1986b)

Description. Hasle and Sims (1986a), p. 111, figs. 22-27

Genus Stephanopyxis Ehrenberg (1844d)

Stephanopyxis turris (Greville et Arnott) Ralfs in Pritchard (1861)

Description. Grunow in van Heurck (1882), pl. 83 ter., fig. 12

Genus Thalassionema Grunow in van Heurck (1881)

Thalassionema bacillaris (Heiden) Kolbe (1955)

Description. Hasle and Mendiola (1967), pp. 107-125, figs. 1-4, 6-8, 18-19, 22-26; Hallegraeff (1986), pp. 60-62, fig. 5; Simonsen (1992), p. 25 , pl. 22 , figs. 1-6

Thalassionema nitzschioides Grunow in van Heurck (1881)

Description. Hallegraeff (1986), pp. 58-60, figs. 1-4

Thalassionema nitzschioides var. obtusa (Grunow) M. Peragallo (1903)

Description. Hasle (1960), p. 18, figs. 5b, 5e

Thalassionema nitzschioides var. parva Heiden et Kolbe (1928)

Description. Hasle (1960), p. 18, fig. 5a

Genus Thalassiosira Cleve (1873)

Thalassiosira anguste-lineata (A. Schmidt) Fryxell et Hasle (1977)

Description. Fryxell and Hasle (1977), pp. 73-75, figs. 22-34

Thalassiosira antiqua (Grunow) Cleve-Euler (1941)

Description. Cleve-Euler (1951), p. 72, fig. 119

Thalassiosira cf. decipiens (Grunow) Jørgensen (1905)

Pl. 1, Fig. 18

Description. Hustedt (1930), pp. 322-323, fig. 158

Thalassiosira eccentrica (Ehrenberg) Cleve (1903)

Description. Fryxell and Hasle (1972), pp. 300-312, figs. 1-18

Thalassiosira ferelineata Hasle et Fryxell (1977)

Description. Hasle and Fryxell (1977), pp. 26-28, figs. 46-53

Thalassiosira gravida Cleve (1896)

Description. Cleve (1896), p. 12, pl. 2, figs. 14-16; Hustedt (1930), p. 325 , fig. 161; Syvertsen (1979), pp. 52-54

Thalassiosira latimarginata Makarova (1975)

Synonym. Thalassiosira trifulta Fryxell in Fryxell et Hasle (1979) pp. 16-19. figs. 1-24

Description. Makarova (1975), p. 150, figs. 3-4

Thalassiosira leptopus (Grunow) Hasle et Fryxell (1977)

Description. Hasle and Fryxell (1977), pp. 20-22, figs. 1-14, 94-96

Thalassiosira lineata Jousé (1968)

Description. Hasle and Fryxell (1977), pp. 22-23, figs. 15-25

Thalassiosira nidulus (Tempère et Brun) Jousé (1961)

Pl. 4, Fig. 5

Description. Jousé (1961), p. 63. pl. 3, figs. 4-5

Thalassiosira oestrupii (Ostenfeld) Proschkina-Lavrenko var. oestrupii Jousé (1968)

Description. Jousé (1968), pp. 13-15, pl. 1, figs. 3-7

Thalassiosira oestrupii var. plana Jousé (1968)

Description. Jousé (1968), p. 15, pl. 1, figs. 8, 9

Thalassiosira symmetrica Fryxell et Hasle (1972)

Description. Fryxell and Hasle (1972), p. 312, figs. 37-46

Thalassiosira sp. 1

Pl. 1, Fig. 16

Remarks. Only single fragments of this species were found at Sites 873 and 880 . The valves are convex. The areolae decrease in size toward the margin and form segments. The margin is coarsely striate $(10-11$ striae in $10 \mu \mathrm{m})$. 
Genus Thalassiothrix Cleve et Grunow (1880)

Thalassiothrix longissima Cleve et Grunow (1880) in Cleve et Möller (1878

Description. Hasle and Semina (1987), pp. 177-181, figs. 1-25

Genus Xanthiopyxis Ehrenberg (1944d)

$$
\text { Pl. 4, Fig. } 8
$$

Remarks. No species were differentiated.

\section{ACKNOWLEDGMENTS}

The author thanks the Ocean Drilling Program and the German Science Foundation for her participation in Leg 144. The creativity of Leon Holloway and Glen Foss in developing a tool for improving the quality of sediment cores in the pelagic calcareous sands with high water content is gratefully acknowledged. Thanks to the generosity of P.R.N. Hobbs and B. Buchardt, who shared samples with me so that the detailed study at Site 880 could be performed. I also appreciate the help by B. Piesker, who did the sample preparation; R. Engel, who drew all figures; and E. Bitzer and T. Witczak, who typed the text and tables. The X-ray analysis to check microscopic mineral determinations was done by Dr. $\mathrm{H}$. Rösch at the Bundesanstalt für $\mathrm{Ge}$ owissenschaften Hannover. This paper was reviewed by J.A. Barron and R. Gersonde.

\section{REFERENCES}

Agardh, C.A., 1832. Conspectus criticus diatomacearum, Part 4. Lundae Literis Berlingianis: 48-66.

Akiba, F., and Yanagisawa, Y., 1986. Taxonomy, morphology and phylogeny of the Neogene diatom zonal marker species in the middle-to-high latitudes of the North Pacific. In Kagami, H., Karig, D.E., Coulbourn, W.T., et al., Init. Repts. DSDP, 87: Washington (U.S. Govt. Printing Office), 483-554.

Andrews, G.W., 1976. Miocene marine diatoms from the Choptank Formation, Calvert County, Maryland. Geol. Surv. Prof. Pap. U.S., 910:1-26.

Bailey, J.W., 1856. Notice of microscopic forms found in the soundings of the Sea of Kamtschatka?with a plate. Am. J. Sci., 22:1-6.

Barron, J.A., 1992. Neogene diatom datum levels in the equatorial and North Pacific. In Saito, T., and Ishizaki, K. (Eds.), The Centenary of Japanese Micropaleontology: Tokyo (Terra Scientific), 413-425.

Battarbee, R.W., 1973. A new method for the estimation of absolute microfossil numbers, with reference especially to diatoms. Limnol. Oceanogr., 18:647-653.

Bory de Saint-Vincent, J.B.M., 1822-1831. Collaborator in Dictionaire Classique d'Histoire Naturelle (Vol. 17): Atlas et Illustration des Planches: Paris.

Brightwell, T., 1858. Remarks on the genus "Rhizosolenia" of Ehrenberg. Q. J. Microsc. Sci., 6:93-95.

Castracane, C.A.F. degli Antelminelli, 1866. Catalogo di Diatomee raccolte nella Val Intrasca. Comment. Soc. Crittogamologica Ital., 2(2):214-227 (114-127).

, 1875. Contribuzione alla florula, delle Diatomee del Mediterraneo ossia esame del contenuto dello stomaco di una Salpa pinnata, pescata a Messina. Atti dell' Acad. Pontificia de 'Nuovi Lincei,

Cleve, P.T., 1873. On diatoms from the Arctic Sea. Bihang till Kongl. Sven. Vetensk.-Akad. Handl., 1(13):1-28.

1896. Diatoms from Baffin Bay and Davis Strait. Bihang till Kongl. Sven. Vetensk,-Akad. Handl., Afd. 3, 22(4):1-22.

1900. Plankton from the southern Atlantic and the southern Indian Ocean. Öfvers. af Kongl. Vetensk._Akad. Förhandl., 57(8):9191038.

, 1903. Plankton table for the North Sea. Bull. Cons. Perm. Intern. pour l'Explor. de la Mer, 1903-1904, 216.

Cleve, P.T., and Grunow, A., 1880. Beiträge zur Kenntnis der arktischen Diatomeen. Kongl. Sven. Vetensk. Handl., 17(2):1-121.

Cleve, P.T., and Möller, J.D., 1877-1882. Diatoms (Exsiccata) (Pts. 1-6): Upsala.

Cleve-Euler, A., 1941. Alttertiäre Diatomeen und Silicoflagellaten im Inneren schwedens, gefunden und gezeichtnet von Ake Berg, beschrieben von Asterid Cleve-Euler. Palaeontographica, 92:165-212.
1951. Die Diatomeen von Schweden und Finland. K. Sven. Vetensk. Handl., Fjärde Serien, 1:1-163.

Desikachary, T.V., and Maheshwari, C.L., 1958. Fossil diatoms from Colebrook Island. J. Indian Bot. Soc., 37:27-29.

Ehrenberg, C.G., 1837. Die fossilen Infusorien und die lebendige Dammerde. Abh. K. Akad. Wiss. Berlin.

, 1838. Die Infusionsthierchen als vollkommene Organismen. Ein Blick in das tiefere organische Leben der Natur: Leipzig (Leopold Voss).

1839. Die Bildung der europäischen, libyschen und arabischen Kreidefelsen und des Kreidemergels aus mikroskopischen Organismen, dargestellt und physiologisch erläutert. Abh. Konigl. Akad. Wiss. Berlin, 1838:59-147.

, 1840. Über noch jetzt zahlreich lebende Thierarten der Kreidebildung und den Organismus der Polythalamien. Abh. K. Akad. Wiss. Berlin, 1839:81-174.

, 1841. Verbreitung und Einfluß des mikroskopischen Lebens in Süd- und Nord-Amerika. Abh. Preuss. Akad. Wiss. Berlin Physik.-Math. Kl. $4: 291-446$.

1844a. Einige vorläufige Resultate der Untersuchungen der von der Südpolreise des Captain Ross, sowie in den Herren Schayer und Darwin zugekommenen Materialien über das Verhalten des kleinsten Lebens in den Ozeanen und den größten bisher zugänglichen Tiefen des Weltmeeres. K. Preuss. Akad. Wiss. Berlin, Berichte, 182-207.

, 1844b. Mittheilung uber zwei neue Lager von Gebirgsmassen aus Infusonien als Meeres-Absatz in Nord-Amerika und eine Vergleichung derselben mit den organischen Kreide-Gebilden in Europa und Afrika. $K$. Preuss Akad. Wiss. Berlin, Berichte, 1844:57-97.

1844c. Uber das kleinste Leben im Weltmeer am Südpol und in den Meerestiefen: Berlin.

-, 1844d. Untersuchungen über die kleinsten Lebensformen im Quellenlande des Euphrats und Araxes, sowie über eine an neuen Formen sehr reiche marine Tripelbildung von den Bermuda-Inseln. $K$. Preuss. Akad. Wiss. Berlin, Berichte, 253-275.

,- 1845 . Neue Untersuchungen über das kleinste Leben als geologisches Moment. Mit kurzer Charakteristik von 10 neuen Genera und 66 neuen Arten. K. Preuss. Akad. Wiss. Berlin, Berichte, Jahrb. 1845:53-88. , 1854. Mikrogeologie: Das Erden und Felsen schaffende Wirken des unsichtbar kleines selbständigen Lebens auf der Erde: Leipzig (Leopold Voss).

Fenner, J., 1985. Late Cretaceous to Oligocene planktonic diatoms. In Bolli, H.M., Saunders, J.B., and Perch-Nielsen, K. (Eds.), Plankton Stratigraphy: Cambridge (Cambridge Univ. Press), 713-762.

Fenner, J.M., 1991. Late Pliocene-Quaternary quantitative diatom stratigraphy in the Atlantic sector of the Southern Ocean. In Ciesielski, P.F., Kristoffersen, Y., et al., Proc. ODP, Sci. Results, 114: College Station, TX (Ocean Drilling Program), 97-121.

Fryxell, G.A., and Hasle, G.R., 1972. Thalassiosira eccentrica (Ehrenberg) Cleve, $T$. symmetrica sp. nov., and some related Centric diatoms. J. Phycol., 8:297-317.

1977. The genus Thalassiosira: some species with a modified ring of central strutted processes. Nova Hedwigia Beih., 54:67-98.

, 1979. The genus Thalassiosira: T. trifulta sp. nova and other species with tricolumnar supports on strutted processes. Nova Hedwigia Beih., 64:13-40.

Fryxell, G.A., Sims, P.A., and Watkins, T.P., 1986. Azpeitia (Bacillariophyceae): related genera and promorphology. Syst. Bot. Monogr., 13:174.

Gerloff, J., 1970. Elektronenmikroskopische Untersuchungen an Diatomeenschalen. VII. Der Bau der Schale von Planktoniella sol (Wallich) Schütt. Nova Hedwigia Beih., 31:203-219.

Gersonde, R., and Schrader, H.J., 1984. Marine planktic diatom correlation of lower Messinian deposits in the western Mediterranean. Mar. Micropaleontol., 9:93-110.

Greville, R.K., 1859. Descriptions of diatomaceae observed in Californian guano. Q. J. Microsc. Sci., 7:155-166.

1860. A monograph of the genus Asterolampra, including Asteromphalus and Spatangidium. Trans. Microsc. Soc. London, New Ser. 8:102-124.

1863. Descriptions of new genera and species of diatoms from the South Pacific (Pt. 3). Trans. Bot. Soc. Edinburgh, 8:232-238.

1865. Descriptions of new and rare diatoms. Series 14. Trans. Microsc. Soc. London, New Ser., 13:1-37.

Grove, E., and Sturt, G., 1886-1887. On a fossil marine diatomaceous deposit from Oamaru, Otago, New Zealand (Pt. 4). J. Quekett Microsc. Club, Ser. 2, 3:131-148. 
Grunow, A., 1867. Algae. Reise seiner Majestät Fregatte Novara um die Erde (in den Jahren 1857, 1858, 1859). Botanischer Teil, Kaiserl.königl. Hof- und Staatsdruckerei, Wien, 1:1-104.

, 1877. New diatoms from Honduras, with notes by F. Kitton. Monthly Microsc. J., 18:165-186.

1884. Die Diatomeen von Franz-Josefs-Land. Denkschr. Kaiserl. Akad. Wiss., Wien, Mathem.-Naturw. Classe, 48:53-112.

Hallegraeff, G.M., 1986. Taxonomy and morphology of the marine planktonic diatoms Thalassionema and Thalassiothrix. Diatom Res., 1:57-80.

Hasle, G.R., 1960. Phytoplankton and ciliate species from the tropical Pacific. Skr. Nor. Vidensk. Akad.-Kl. I: Mat.-Naturv. Kl., 2:1-50.

Hasle, G.R., and Fryxell, G.A., 1977. The genus Thalassiosira: some species with a linear areola array. Nova Hedwigia Beih., 54:15-66.

Hasle, G.R., and Mendiola, B.R.E., 1967. The fine structure of some Thalassionema and Thalassiothrix species. Phycologia, 6:107-125,

Hasle, G.R., and Semina, H.J., 1987. The marine planktonic diatoms Thalassiothrix longissima and Thalassiothrix antarctica with comments on Thalassionema spp, and Synedra reinboldii. Diatom Res., 2:175-192.

Hasle, G.R., and Sims, P.A., 1986a. The diatom genera Stellarima and Symbolophora with comments on the genus Actinoptychus. Br. Phycol. J., 21:97-114

1986b. The diatom genus Coscindiscus Ehrenb.: C. argus Ehrenb. and C. radiatus Ehrenb. Bot. Mar., 29:305-318.

Hassall, A.H., 1845. A History of British Freshwater Algae (Including Descriptions of the Diatomaceae and Desmidiaceae) with Upwards of One Hundred Plates (Vols. 1 and 2): London (Taylor, Walton, and Maberly).

Heiberg, P.A.C., 1863. Conspectus Criticus Diatomacearum Danicarum. Kjobenhavn (Wilhelm Priors Forlag).

Heiden, H., and Kolbe, R.W., 1928. Die marinen Diatomeen der Deutschen Südpolar-Expedition 1901-1903. In von Drygalski, E. (Ed.), Deutsche Sïdpolar-Expedition 1901-1903 (Vol. 8): Berlin (Walter de Gruyter), $447-715$.

Hendey, N.I., 1964. An Introductory Account of the Smaller Algae of British Coastal Waters. Fish. Invest. Ser. 4 (Pt. 5), Bacillariophyceae (Diatoms): London (HMNO).

Héribaud, J., 1893. Les Diatomées d'Auvergne: Paris (Librairie des Sciences Naturelles), 1-233.

Hustedt, F., 1913. Tafel 285-300. In Dr. A. Schmidt's Atlas der Diatomaceenkunde mit vorläufigen Erläuterungen: Bremen ( $\mathrm{F}$. Hustedt).

1914. Tafel 301-316. In Dr. A. Schmidt's Atlas der Diatomaceenkunde mit vorläufigen Erläuterungen: Bremen (F. Hustedt).

1920. Plates 317-328 with descriptions. In Dr. A. Schmidts Atlas der Diatomaceenkunde mit vorläufigen Erläuterungen: Bremen ( $\mathrm{F}$. Hustedt).

1930. Die Kieselalgen Deutschlands, Österreichs und der Schweiz unter Berücksichtigung der übrigen Länder Europas sowie der angrenzenden Meeresgebiete. Teil 1. In Rabenhorst, L. (Ed.), Kryptogamen-Flora von Deutschland, Österreich und der Schweiz (Vol, 7): Leipzig (Akad. Verlag).

1933. Die Kieselalgen Deutschlands, Österreichs und der Schweiz unter Berücksichtigung der übrigen Länder Europas sowie der angrenzenden Meeresgebiet. In Rabenhorst, L. (Ed.), KryptogamenFlora von Deutschland, Österreich und der Schweiz. (Vol. 7): Leipzig (Akad. Verlag), 321-576.

1958. Die diatomeen aus der Antarktis und dem Sudatlantik. Dtsch. Antarkt. Exped. 1938-1939, 2:103-191.

. 1959. Die Kieselalgen Deutschlands, Österreichs und der Schweiz unter Berücksichtigung der übrigen Länder Europas sowie der angrenzenden Meeresgebiete. In Rabenhorst, L. (Ed.), Rabenhorst's Kryptogamen-Flora von Deutschland, Österreich und der Schweiz (Vol. 7) (2nd ed.): Leipzig (Akad. Verlag).

Ivanik, M.M., 1983. Paleogene and Neogene sponge spicules from Sites 511, 512, and 513 in the South Atlantic. In Ludwig, W.J., Krasheninnikov, V.A., et al., Init, Repts. DSDP, 71 (Pt. 2): Washington (U.S. Govt. Printing Office), 933-950.

Jordan, R.W., and Priddle, J., 1991. Fossil members of the diatom genus Proboscia. Diatom Res., 6:55-61.

Jørgensen, E., 1905. Protistplankton. Diatoms in bottom samples. In Nordgaard, O., Hydrographical and Biological Investigations in Norwegian Fjords: Bergens Museums Skrift, Bergen (John Grieg).

Jousé, A.P., 1961. Diatomeae marinae Mioceni et Plioceni ex oriente extremo. Botan. Mater. otdela Spor. Rast. (Notulae System. e Sect. Crypt. Inst. Botan. Nom. V. L. Komarovii Acad. Scient. U.R.S.S.), 14:59-70.
1968. Species novae Bacillariophytorum in sedimentis fundi Oceani Pacifici et Maris Ochotensis inventae. Novit. syst. Plant. non Vasc., Acad. Nauk S.S.S.R., 1968:12-21.

Jousé, A.P., Koroleva, G.S., and Negaeva, G.A., 1962. Diatoms in the surface layer of sediment in the Indian sector of the Antarctic. Tr. Inst. Okeanol., Akad. Nauk SSSR, 61:19-92.

Karsten, G., 1907. Das Indische phytoplankton. Wissenschaftliche Ergebnisse der deutschen Tiefsee-Expedition auf dem Dampfer "Valdivia" 1898-1899. von Carl Chun. G. Karsten, Jena, 223-544.

Koblentz-Mishke, O.J., Volkovinsky, V.V., and Kabanova, J.G., 1970. Plankton primary production of the world ocean. In Wooster, W.S. (Ed.), Scientific Exploration of the South Pacific: Washington (Natl. Acad. Sci.), 183-193.

Koizumi, I., 1972. Marine diatom flora of the Pliocene, Tatsunokuchi Formation in Fukushima Prefecture. Trans. Proc. Paleontol. Soc. Jpn., New Ser., 86:340-359.

Kolbe, R.W., 1955. Diatoms from equatorial Atlantic cores. Rep. Swed. Deep-sea Exped., 1947-1948, 7:149-184.

Kützing, F.T., 1833. Synopsis Diatomacearum oder Versuch einer systematischen Zusammenstellung der Diatomeen. Limnaea, 8:529-620.

Lange, C.B., and Syvertsen, E.E., 1989. Cyclotella litoralis sp. nov. (Bacillariophyceae), and its relationships to $C$. striata and $C$. stylorum. Nova Hedwigia Beih., 48:341-356.

Lemmermann, E., 1900. Beiträge zur Kenntnis der Planktonalgen. Ber. Dtsch. Bot. Ges., 18:24-32

Lévi, C., 1964. Spongiaires des zones bathyale, abyssale et hadale. Galathea Rep., 7:63-112.

Makarova, I.V., 1975. Novie vidi roda Thalassiosira Cl. iz Ledenieva morja. Nov. Sist. Nizshikh Rast., 12C:149-152.

McCartney, K., 1990. Siliceous sponge spicules from Ocean Drilling Program Leg 113. In Barker, P.F., Kennett, J.P., et al., Proc. ODP, Sci. Results, 113: College Station, TX (Ocean Drilling Program), 963-970.

Medlin, L.K., and Sims, P.A., 1993. The transfer of Pseudoeunotia doliolus to Fragilariopsis. Nova Hedwigia Beih., 106:323-334.

Peragallo, H., 1892. Monographie du genre Rhizosolenia et de quelques genres voisins. Le Diatom., 1:79-82, 99-117.

Peragallo, M., 1903. Le Catalogue Général des Diatomées. Clermont-Ferrand, 472-973.

Premoli Silva, I., Haggerty, J., Rack, F., et al., Proc. ODP, Init. Repts., 144: College Station, TX (Ocean Drilling Program).

Pritchard, A., 1861. A History of Infusoria, Living and Fossil Including the Desmidiaceae and Diatomaceae British and Foreign (4th ed., revised and enlarged by Arlidge, J.T., Archer, W., Ralfs, J., Williamson, W.C., and the author): London (Whittaker and Co.).

Rattray, J., 1890. A revision of the genus Coscinodiscus Ehrenb., and some allied genera. Proc. Royal Soc. Edinburgh, 16:449-692.

Round, F.E., and $\mathrm{H}$ kansson, H., 1992. Cyclotelloid species from a diatomite in the Harz mountains, Germany, including Pliocaenicus gen. nov. Diatom Res., 7:109-125.

Schmidt, A., Schmidt, M., Fricke, F., Heiden, H., Müller, O., and Hustedt, F., 1874-1959. Atlas der Diatomeen-Kunde: Leipzig (R. Reisland).

Schulze, F.E., 1899. Amerikanische Hexactinelliden nach dem Materiale der Albatross Expedition - mit einem Atlas: Jena (Verlag Gust. Fisch.).

Schütt, F., 1893. Das Pflanzenleben der Hochsee: Kiel (Verlag Lipsius \& Tischer).

Shadbolt, G., 1854. A short description of some new forms of Diatomaceae from Port Natal. Trans. Microsc. Soc. London, New Ser., 2:13-18.

Simonsen, R., 1974. The diatom plankton of the Indian Ocean expedition of R/V Meteor, 1964-1965. "Meteor" Forschunsergeb., Reihe D, 19:1107.

1979. The diatom system: ideas on phylogeny. Bacillaria, 2:9-71.

Simonsen, R., 1992. The diatom types of Heinrich in Heiden \& Kolbe 1928. Bib. Diatom., 24.

Sundstrom, B.G., 1986. The marine datom genus Rhizosolenia. A new approach to the taxonomy [Ph.D. thesis]. Univ. Gothorum Carolinae, Sweden.

Syvertsen, E.E., 1979. Resting spore formation in clonal cultures of Thalassiosira antarctica Comber, T. nordenskioeldii Cleve, and Detonula confervacea (Cleve) Grun. Nova Hedwigia Beih., 64:41-63.

Tempère, J., and Peragallo, H., 1912. Diatomées du Monde Entier (2nd ed.): Arcachon (S.-et-M.), 305-352.

Tempère, J., and Peragallo, H., and Peragallo, M., 1910. Diatomées du Monde Entier (2nd ed.): Arcachon (S.-et-M.), 209-256.

Tendal, O.S., 1973. Sponges collected by the Swedish Deep Sea Expedition. Zool. Scr., 2:33-38. 
Thorington-Smith, M., 1970. Some new and little-known planktonic diatoms from the West Indian Ocean. Nova Hedwigia Beih., 31:815-835.

Thwaites, G.H.K., 1848. Further observations on the Diatomaceae with descriptions of new genera and species. Annals Mag. Nat. Hist., Ser. 2 , 20:161-172.

Van Heurck, H., 1880-1885. Synopsis des Diatomées de Belgique. Atlas (1880-1881), Texte (1885). Anvers (Ducaju et Cie).

Wallich, G.C., 1860. On the siliceous organisms found in the digestive cavities of the $\mathrm{S}$ alpae, and their relation to the flint nodules of the Chalk Formation. Trans. Microsc. Soc. London, New Ser., 8:36-55.

Whiting, M.C., and Schrader, H.-J., 1985. Actinocyclus ingens Rattray: reinvestigation of a polymorphic species. Micropaleontology, 31:68-75.
Wiedenmayer, F., 1977. Shallow-water Sponges of the Western Bahamas: Basel (Verlag Birkhäuser).

Yanagisawa, Y., and Akiba, F., 1990. Taxonomy and phylogeny of three marine diatom genera, Crucidenticula, Denticulopsis, and Neodenticula. Bull. Geol. Surv. Jpn. [Chishitsu Chosasho Geppo], 41:197-301.

Date of initial receipt: 2 February 1994

Date of acceptance: 28 July 1994

Ms 144SR-006 


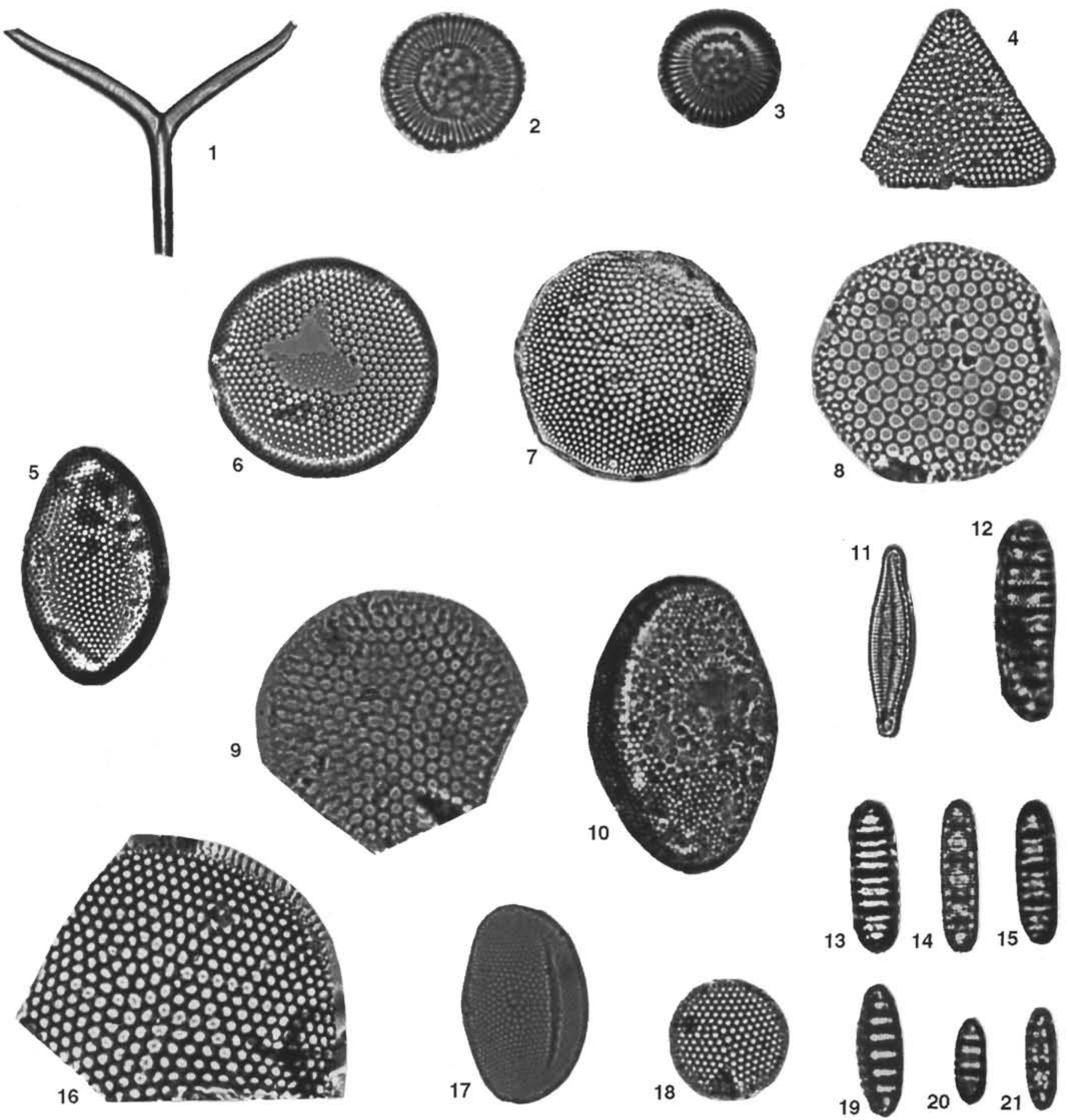

Plate 1. Marine planktonic diatoms in Quaternary sediments. Magnification $1500 \times$, except for Figure 7, which is at $975 \times$. 1. Chaetoceros messanensis, Sample 144-880A-1H-1, 73-74 cm. 2-3. Cyclotella litoralis; (2) Sample 144-880A-1H-1, $60 \mathrm{~cm}$; (3) Sample 144-880A-1H-1, $24 \mathrm{~cm}$. 4. Pseudotriceratium cinnamomeum, Sample 144-880A-1H-1, 46 cm. 5. Hemidiscus sp. 1, Sample 144-880A-1H-2, 59-60 cm. 6. Actinocyclus sp. 1, Sample 144-880A-1H-2, 9-10 $\mathrm{cm}$. 7. Actinocyclus curvatulus, Sample 144-873B-1H-1,30-34 cm. 8. Coscinodiscus radiatus, Sample 144-880A-1H-1, 60 cm. 9. Thalassiosira sp., Sample 144-880A-1H-1, 42 cm. 10. Hemidiscus? sp., Sample 144-880A-1H-1, 30 cm. 11. Nitzschia interruptestriata, Sample 144-880A-1H-1, 129-130 cm. 12. Denticulopsis lauta, Sample 144-880A-1H-1, 48 cm. 13-15. Neodenticula seminae, 13; Sample 144-880A-1H-1, base. 14. Sample 144-880A-1H-1, $18 \mathrm{~cm}$. 15. Sample 144-880A-1H-1, $24 \mathrm{~cm}$. 16. Thalassiosira sp. 1, Sample 144-880A-1H-1, $24 \mathrm{~cm}$. 17. Hemidiscus cuneiformis var., Sample 144-880A-1H-1, 32 cm. 18. Thalassiosira aff. decipiens, Sample 144-880A-1H-1,73-74 cm. 19-21. Neodenticula kamtschatica; (19) Sample 144-880A-1H-1, 14 cm; (20) Sample 144-880A-1H-1, $36 \mathrm{~cm}$; (21) Sample 144-880A-1H-1, $18 \mathrm{~cm}$. 


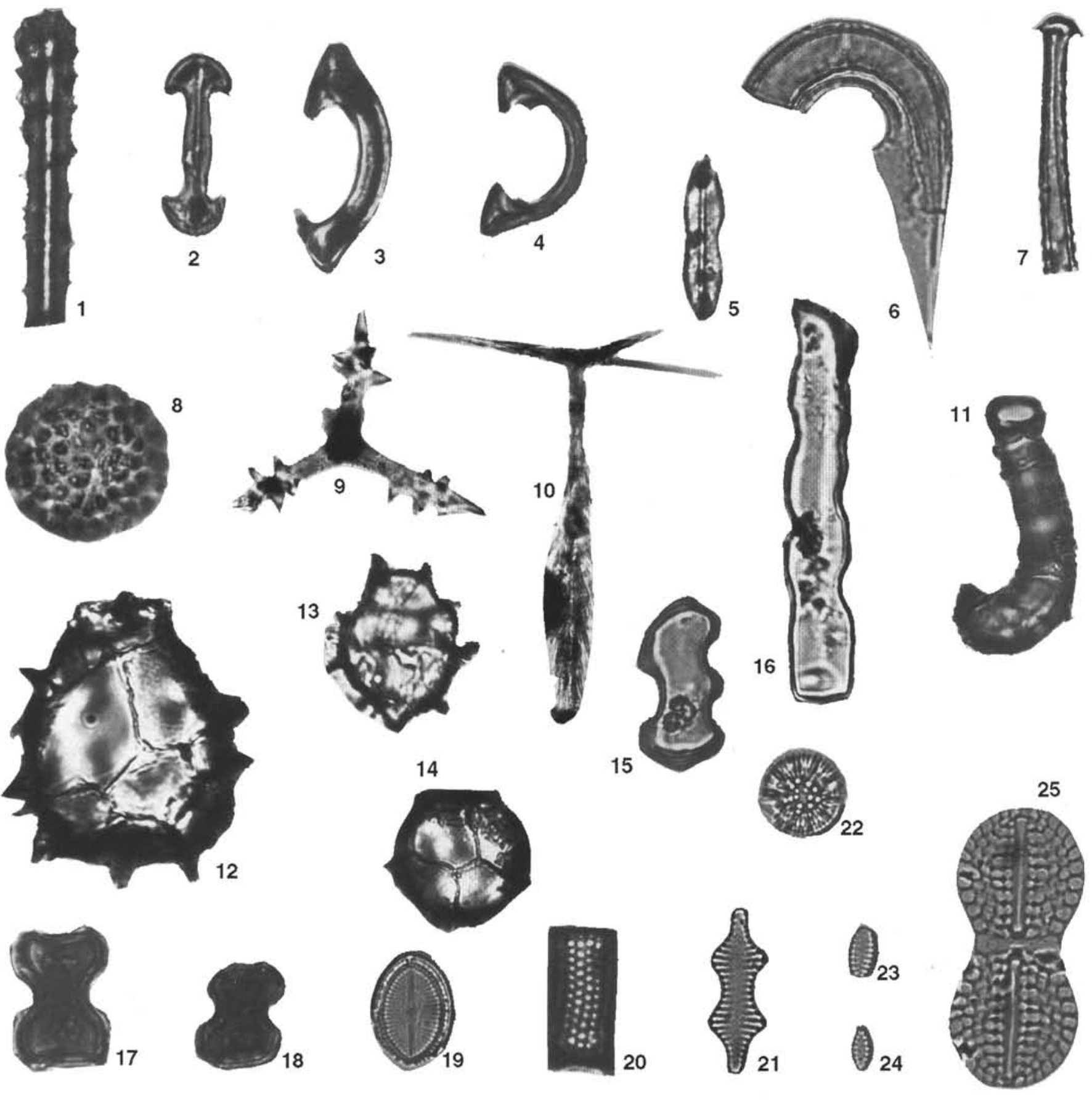

Plate 2. Magnification 1500x, except for Figures 1, 9, 11, and 13 at $975 \times$; Figures 8 and 14 at $625 \times$; and Figure 10 at $300 \times$. Figures 1-10 represent siliceous sponge spicules and microscleres. 1. Acanthostyle (m), Sample 144-880A-1H-1, $48 \mathrm{~cm}$. 2-4. Arcuate isochele (m); (2) front view, Sample 144-880A-1H-1, $36 \mathrm{~cm}$; (3) side view, Sample 144-880A-1H-1, $62 \mathrm{~cm}$; (4) side view, Sample 144-880A-1H-1, $66 \mathrm{~cm}$. 5. Unknown type (m), Sample 144-880A-1H-2, 59-60 cm. 6. Diancistra? (m), Sample 144-880A-1H-1, $62 \mathrm{~cm}$. 7. Fragment of forceps (m), Sample 144-880A-1H-2, 9-10 cm. 8. Sterrospheraster (m), Sample 144-873B-1H-1, 30-34 cm. 9. Acanthotetraxon (m), Sample 144-873B-1H-1,30-34 cm. 10. Pentactinpinul (m), Sample 144-878A-1H-1 (top). 11. Organic walled tube, Sample 144-880A-1H-1, $66 \mathrm{~cm}$. Figures 12-14 are dinoflagellates. 12. Sample 144-872A-1H-5, $39-43 \mathrm{~cm} .13$. Sample 144-872A-1H-4, 140-144 cm. 14. Sample 144-872A-1H-CC. Figures $15-18$ are phytoliths. 15. Sample $144-880 \mathrm{~A}-1 \mathrm{H}-1,62 \mathrm{~cm}$. 16. Sample 144-880A-2H-2, 49-50 cm. 17. Sample 144-880A-1H-1, $6 \mathrm{~cm}$. 18. Sample 144-880A-1H-1, $46 \mathrm{~cm}$. Figures 19-25 are freshwater diatoms. 19. Cocconeis placentula. Sample 144-880A-1H-1, 36 cm. 20. Aulacoseira sp., Sample 144-880A-1H-1, 26 cm. 21. Fragilaria sp., Sample 144-880A-1H-1, $18 \mathrm{~cm}$. 22. Cyclotella radiosa, Sample 144-880A-1H-1, base. 23, 24. Fragilaria sp.; (23) Sample 144-880A-1H-1, 58 cm; (24) Sample 144-880A-1H-1, 60 cm. 25. Diploneis sp., Sample 144-880A-1H-1, 66 cm. 

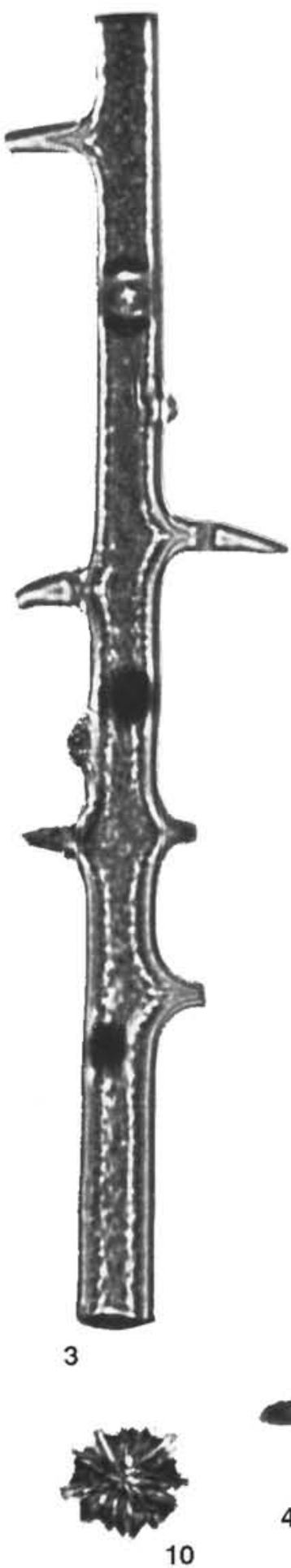
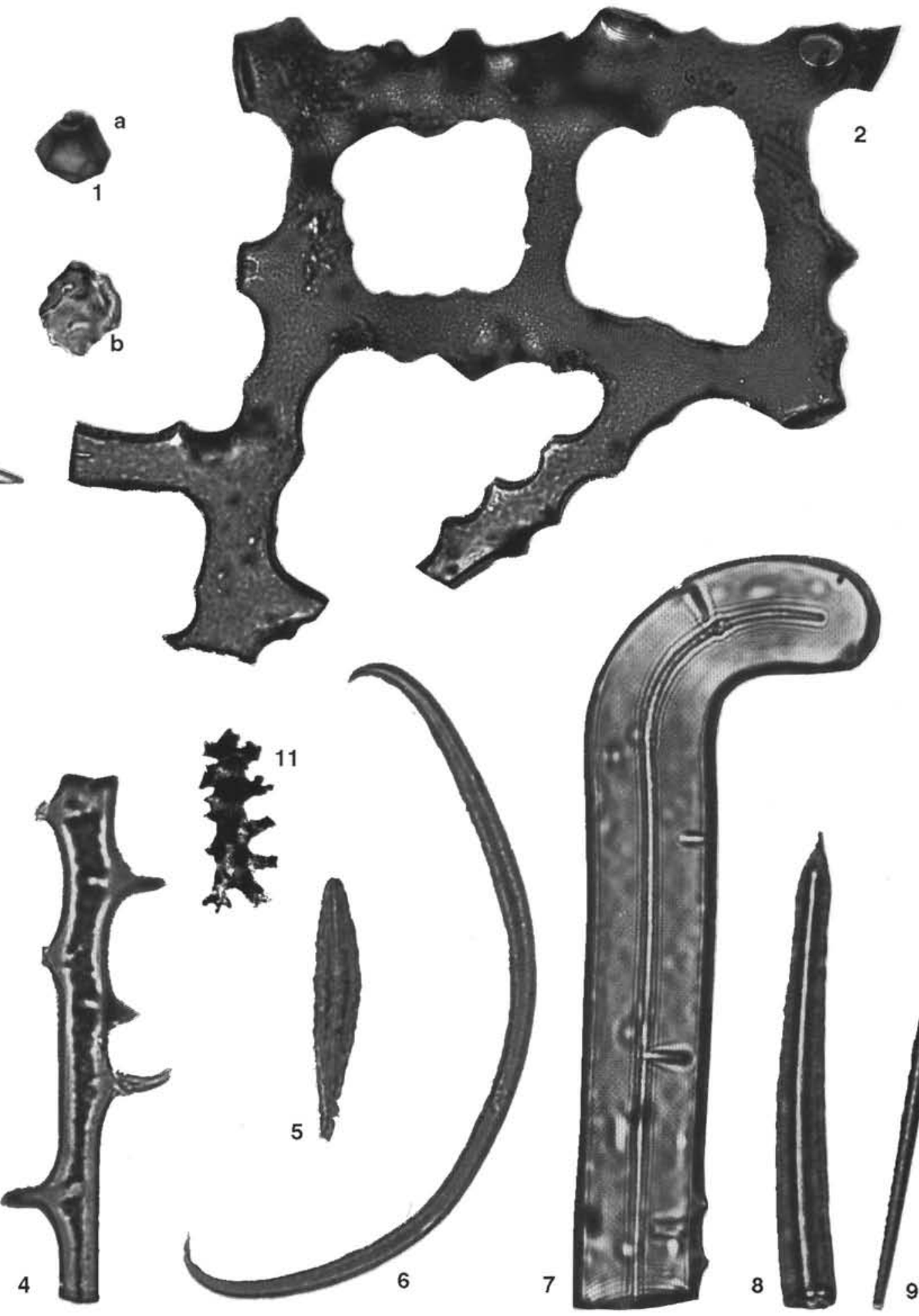


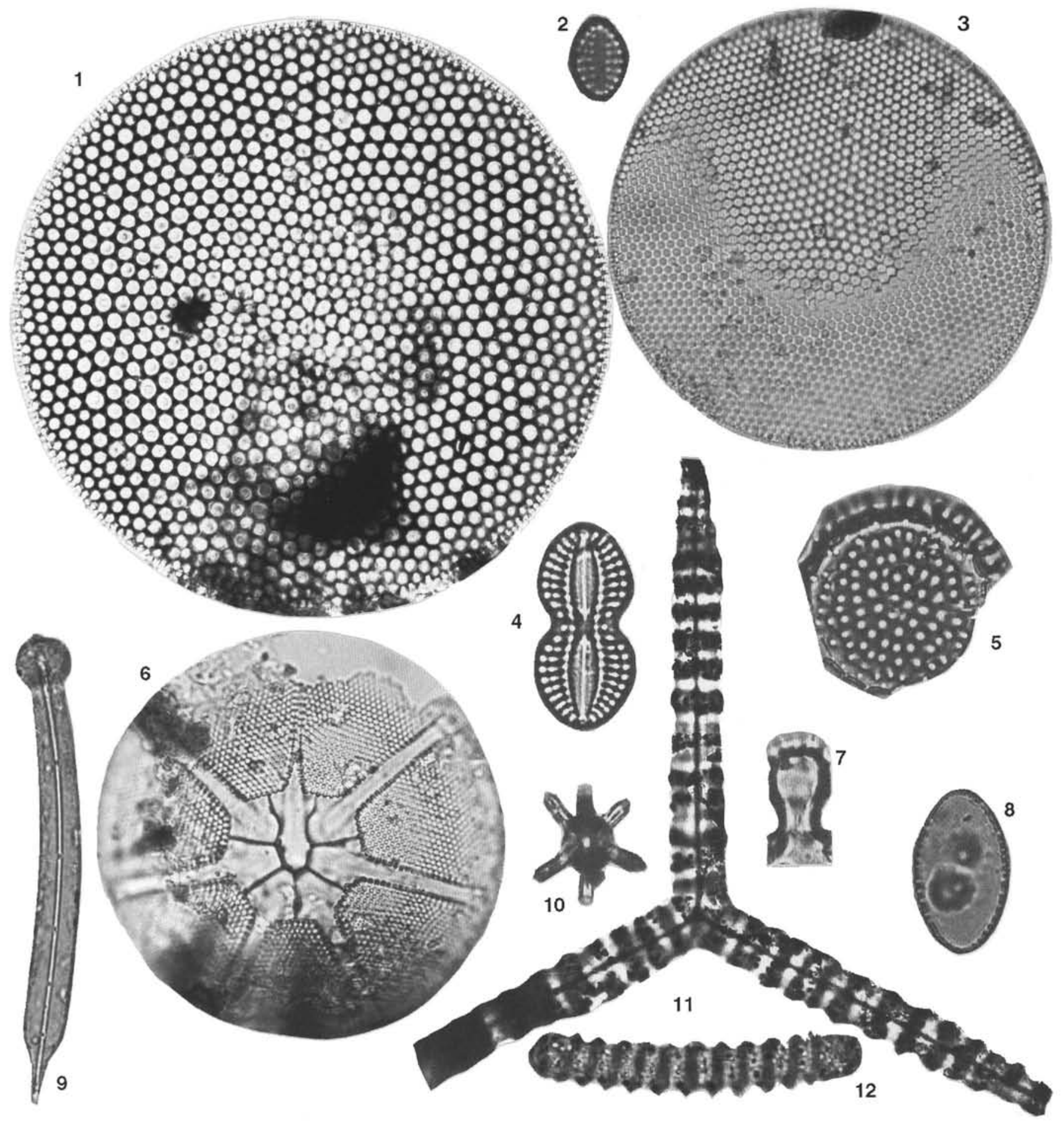

Plate 4. Magnification 1500×, except Figures 1, 3, 6, 9, 12 at 975×. Figures 1-8 are marine diatoms. 1. Coscinodiscus pacificus, Sample 144-878H-1R-CC. 2. Rhaphoneis surirelloides, Sample 144-880A-1H-1, 24 cm. 3. Planktoniella sol, Sample 144-878-1H-1 (top). 4. Diploneis bombus, Sample 144-880A-1H-1, 129-130 cm. 5. Thalassiosira jouseae (T. nidulus), Sample 144-880A-1H-1, $66 \mathrm{~cm}$. 6. Asteromphalus ornithopus, Sample 144-878A-1H-1 (top). 7. Diatom resting spore, Sample 144-880A-1H-1, 2 cm. 8. Xanthiopyxis sp., Sample 144-880A-1H-1, $28 \mathrm{~cm}$. Figures 9-12 are siliceous sponge spicules. 9. Tylostyle (m), Sample 144-873B-1H-1, 30-34 cm. 10. Strongylaster (m), Sample 144-880A-1H-1, $64 \mathrm{~cm} . \quad$ 11. Tetraxon (M), Sample 144-873B-1H-2, 0-2 cm. 12. Strongyle (m), Sample 144-873B-1H-1,30-34 cm. 